\title{
NSM TECHNIQUE TO INCREASE THE LOAD CARRYING CAPACITY OF CONTINUOUS RC SLABS
}

Gláucia M. Dalfré ${ }^{1}$, Joaquim A. O. Barros ${ }^{1,2}$

${ }^{1}$ ISISE, University of Minho, Guimarães, Portugal; ${ }^{2}$ Corresponding Author

\begin{abstract}
This work presents and analysis the results of an ongoing research project on the use of the near surface mounted (NSM) carbon fiber-reinforced polymer (CFRP) laminates for the increase of the load carrying capacity of statically indeterminate (two spans) reinforced concrete (RC) slabs. The test program consisted of seventeen slab strips, grouped in two series that are different on the adopted strengthening scheme: $\mathrm{H}$ series, where $\mathrm{H}$ is the notation to identify the slabs strengthened with NSM CFRP laminates exclusively applied in the hogging region; HS series, where HS is the notation to identify the slabs strengthened with NSM CFRP laminates applied in both hogging and sagging regions. The program includes six unstrengthened reference RC slab strips, and eleven strengthened with CFRP NSM configurations designed to increase in $25 \%$ or $50 \%$ the load carrying capacity of the corresponding reference RC slabs. An extensive monitoring system was applied in the constituent materials, in the critical regions of the tested slabs, in order to collect information for the discussion about the effectiveness of NSM technique in terms of load carrying and moment redistribution capacity. The strengthening procedures adopted in the laboratory tests followed, as much as possible, the real strengthening practice for this type of interventions. The obtained results show that the proposed technique is able to increase significantly the load carrying capacity of statically indeterminate RC slabs, even for those with relatively high steel reinforcement ratios. The load carrying capacity of the strengthened slabs was limited by its shear capacity or by the detachment of the strengthened concrete cover layer. At failure of the strengthened slabs, the longitudinal steel bars at intermediate support (hogging region) and at loaded sections (sagging regions) have already yielded, and the deflection was quite large. However, for some strengthening configurations, the CFRP laminates led to a decrease of the moment redistribution capacity of the slabs.
\end{abstract}

\section{HIGHLIGHTS}

Eleven slab strips flexurally strengthened with NSM CFRP laminates were tested. Two different arrangements of CFRP laminates were applied in the slab strips. The increase of the load carrying and moment redistribution capacities was analyzed. The target increase of the load carrying capacity was attained for HS configurations.

Some strengthening configurations led to a decrease of the moment redistribution capacity.

KEYWORDS: Continuous RC slabs, Flexural strengthening, CFRP, NSM, Moment redistribution 


\section{INTRODUCTION}

In general, when a Reinforced Concrete (RC) element is strengthened with fiber reinforced polymer (FRP) systems, its failure mode tends to be more brittle than its unstrengthened homologous element, due to the intrinsic bond conditions between these systems and the concrete substrata, as well as the linear-elastic brittle tensile behavior of the FRP. In fact, the premature debonding of the FRP strengthening systems can significantly reduce the ductility of a flexurally strengthened RC element [1-4]. Debond in the present context is regarded as the phenomena that governs the liaisons FRP-adhesive and adhesive-concrete, as well as the adhesive rupture and the splitting of the concrete surrounding the FRP systems. In case of continuous RC slabs and beams (statically indeterminate structures), the use of FRP systems to increase their flexural resistance can even compromise the moment redistribution capacity and ductility performance of these types of structural elements.

The Externally Bonded Reinforcement, EBR [5-6], and the Near Surface Mounted, NSM [7-8] are the most used techniques for the strengthening of RC elements. However, when compared to EBR, the NSM technique is especially appropriate to increase the negative bending moments (in the intermediate supports, herein designated by hogging regions) of continuous RC slabs, since its strengthening process is simpler and faster to apply than other FRP-based techniques [7]. Furthermore, since the laminates are inserted into thin slits open on the concrete cover, they are protected against external agents and do not create any type of obstacle to the normal functionality of the slab.

The efficiency of the NSM technique for the flexural [9-15] and shear [16-19] strengthening of RC members has already been assessed. However, most of the tests were carried out with NSM strengthened simply supported elements.

Although many in situ RC strengthened elements are of continuous construction nature, there is a lack of experimental and theoretical studies in the behavior of statically indeterminate RC members strengthened with FRP materials. The majority of research studies dedicated to the analysis of the behavior of continuous elements reports the use of the EBR technique [4, 2, 20-22]. Limited information is available in literature dealing with the behavior of continuous structures strengthened according to the NSM technique [23, 13, 24].

In this paper the potentialities of the NSM technique are explored for the increase of the load carrying capacity of two spans continuous RC slabs. The NSM strengthening configurations applied in eleven slab strips were designed to increase, in $25 \%$ and $50 \%$, the load carrying capacity of its corresponding unstrengthened reference RC slab. Besides the load carrying capacity of the tested slabs, the moment redistribution issues are also discussed in this paper.

\section{THE EXPERIMENTAL PROGRAM}

\subsection{Slab specimens and strengthening technique}


The experimental program is composed of seventeen $120 \times 375 \times 5875 \mathrm{~mm}^{3}$ RC slab strips. Six of them were unstrengthened RC slabs forming a control set (SL15-H/HS, SL30-H/HS and SL45-H/HS), and the other eleven slabs were strengthened with CFRP strips according to the NSM technique (SL15s25-H, SL15s50-H/HS, SL30s25H/HS, SL30s50-H/HS, SL45s25-H/HS and SL45s50-H/HS). The notation adopted to identify each slab specimen is SLxsy-z, where SL is the slab strip base, $\mathrm{x}$ is the moment redistribution percentage $(\eta)$, s means that the slab strip is strengthened, $\mathrm{y}$ is the target increase in the load carrying capacity, and $\mathrm{z}=\mathrm{H}$ or $\mathrm{z}=\mathrm{HS}$ when the slab is strengthened in the hogging region or in both hogging and sagging regions (HS), respectively. According to CEB-FIP Model Code [25], the moment redistribution for RC slabs should be limited to $25 \%$, but the possibility of attaining a $\eta=15$, 30 or $45 \%$ was explored in the present work.

The geometry, support and load conditions, and the reinforcement and strengthening arrangements are represented in Figs. 1 to 5 . Additionally, the details of the cross sections of the slab strips are presented in Table 1, where $\rho_{l, e q}^{H}$ and $\rho_{l, e q}^{S}$ are the equivalent steel reinforcement ratio $\left[\rho_{l, e q}=A_{s} /\left(b d_{s}\right)+\left(A_{f} E_{f} / E_{s}\right) /\left(b d_{f}\right)\right]$ of the hogging and sagging regions, respectively, where $b$ is the width of the slab's cross section and $d_{s}$ and $d_{f}$ are the effective depth of the longitudinal steel bars and CFRP laminates, respectively, and $E_{s}$ and $E_{f}$ are the Young's Modulus of the longitudinal tensile steel bars and CFRP laminates.

The steel reinforcement arrangements in the reference slabs (with the designations of SL15-H/HS, SL30-H/HS and SL45-H/HS) were designed in compliance with ACI 318 [26]. According to this recommendation, the maximum applied load due to deformability requirements should not introduce a deflection higher than L/480, where $\mathrm{L}$ is the span length of the slab $(\mathrm{L}=2800 \mathrm{~mm})$. In this way, taking into account the concrete compressive strength of each series, the target design load was $50.82 \mathrm{kN}$ for the $\mathrm{H}$ series and $46.20 \mathrm{kN}$ for the HS series, respectively, maintaining the same steel arrangement in both H and HS series. Furthermore, in the evaluation of the reinforcement percentages a coefficient of moment redistribution $(\eta)$ equal to 15,30 or $45 \%$ was considered.

According to the CEB-FIB Model Code [25], the coefficient of moment redistribution, $\delta=M_{\text {red }} / M_{\text {elas }}$, is defined as the relationship between the moment at the critical section after redistribution $\left(M_{\text {red }}\right)$ and the elastic moment ( $\left.M_{\text {elas }}\right)$ at the same section calculated according to the theory of elasticity, while $\eta=(1-\delta) \cdot 100$ is the moment redistribution percentage. The percentage of steel reinforcement, as well as the percentage of CFRP laminates applied in the critical sections of the slabs, were evaluated for the bending moments after moment redistribution has been implemented, by adopting for the maximum compressive strain in the concrete the value of $3.5 \%$, in agreement with CEB-FIB Model Code recommendations.The NSM flexurally strengthened slabs had the same steel 
reinforcement arrangements adopted in the reference slabs of the corresponding series. The number of CFRP laminates was designed to increase the load carrying capacity of the reference slabs (REF) in $25 \%$ and $50 \%$.

The design of cross sections subject to flexure was based on force and moment equilibriums, as well as in strain compatibility, where the maximum strain at extreme concrete compression fiber was assumed equal to $3.5 \%$ and the maximum tensile strain in the CFRP laminates was limited to the value recommended ACI 440 [5] (70\% of the ultimate tensile strain).

\subsection{Strengthening Schemes and Test Configuration}

The tested slab strips, of $120 \times 375 \times 5875 \mathrm{~mm}^{3}$, were grouped in two series depending on the strengthening scheme: $\mathrm{H}$ series, where $\mathrm{H}$ is the notation to identify the slabs strengthened with NSM CFRP laminates exclusively in the hogging region; HS series, where HS is the notation to identify the slabs strengthened with NSM CFRP laminates in both hogging and sagging regions. In both $\mathrm{H}$ and $\mathrm{HS}$ series of RC slabs, the CFRP strengthening ratio was determined in order to provide the increase of the load carrying capacity of the slab strips. The strengthening arrangements represented in Fig. 2 were adopted.

\subsubsection{H series}

This series was composed of the unstrengthened RC slabs (SL15-H, SL30-H and SL45-H), and five strengthened slabs with CFRP strips according to the NSM technique. Two arrangements of CFRP laminates were applied in the hogging region with the purpose of increasing the flexural capacity of the slab cross section at the intermediate support (negative resisting bending moment, $\mathrm{H}$ ) and, consequently, the load carrying capacity of the reference slab in $25 \%$ and $50 \%$. These slabs have the designations of SL15s25-H, SL30s25-H, SL45s25-H and SL15s50-H, SL30s50-H, SL45s50-H, respectively. In this series, CFRP laminates of $1.4 \times 10 \mathrm{~mm}^{2}$ cross section were used. In this series, the slabs were strengthened before having been tested, i.e. no damages exist when these slabs were strengthened.

\subsubsection{HS series}

This series is composed of the reference RC slabs (SL15-HS, SL30-HS and SL45-HS) and the strengthened slab strips (SL15s25-HS, SL30s25-HS, SL30s50-HS, SL45s25-HS and SL45s50-HS). The CFRP laminates were applied in both hogging and sagging regions. If only laminates of $1.4 \times 10 \mathrm{~mm}^{2}$ cross section had been selected to increase the load carrying capacity of the sagging regions, the number of laminates would have been relatively high in these regions, leading to a small distance between laminates, which could favor the occurrence of group effect, with an eventual premature detachment of the concrete cover that includes the laminates [27]. Therefore, for this series, CFRP laminates of $1.4 \times 20 \mathrm{~mm}^{2}$ cross section were preferentially selected. However, in the SL30s25-HS, to avoid the 
placement of a laminate coinciding with the position of an existing longitudinal steel bar that previous research has indicated to be an unfavorable arrangement [7], two laminates of $1.4 \times 10 \mathrm{~mm}^{2}$ cross section were applied instead of one $1.4 \times 20 \mathrm{~mm}^{2}$ laminate.

Each test of the slab strips of HS series had two phases. In the first testing phase the slab was loaded up to attain, in the loaded sections, a deflection corresponding to $50 \%$ of the deflection measured in the reference slab when the steel reinforcement in the hogging region has reached its yield strain. When attained this deflection level (a value that varied between $5.4 \mathrm{~mm}$ and $5.7 \mathrm{~mm}$ ), a temporary reaction system was applied (Fig. 6) in order to maintain this deformability during the period necessary to strengthen the slab. To control the maintenance of this deflection, dial gages were used to adjust the temporary reaction system when necessary. Therefore, the strengthening process was applied to the slab that has a damage level that can be representative of real slabs requiring structural rehabilitation.This criterion seems representative of a level of damage found in these type of structures at serviceability states, when only quasi-permanent loads are actuating. For this loading conditions this type of structures are in the elastic-cracked phase, but the maximum tensile strain in the existing steel reinforcement is in the range between 40 to $60 \%$ of the yield initiation strain. After the curing time of the adhesive used to bond the NSM CFRP strips (which in general took about two weeks), the temporary reaction system was removed, while the load was transferred to the slab. This stress transfer process was governed by the criteria of maintaining the deflection level that corresponds to the initiation of the second phase of the test. This second phase of the test ended when the strengthened slab strip has ruptured.

\subsection{Test configuration and monitoring system}

The six linear voltage differential transducers supported on a suspension yoke (LVDT 82803, LVDT 60541, LVDT 82804, LVDT 19906, LVDT 18897 and LVDT 3468) were used to measure the vertical deflection of a slab strip (Fig. 1b). The LVDTs 60541 and 18897, placed at the slab midspan, were also used to control the test at a displacement rate of $10 \mu \mathrm{m} / \mathrm{s}$ up to the deflection of $50 \mathrm{~mm}$. After this deflection, the internal LVDTs of the actuators were used to control the test at a displacement rate of $20 \mu \mathrm{m} / \mathrm{s}$ up to the failure of the slab strip.

The force $\left(F_{522}\right)$ applied at the left span (Fig. 1b) was measured using a load cell of $\pm 200 \mathrm{kN}$ and accuracy of $\pm 0.03 \%$ (designated as Ctrl_1), placed between the loading steel frame and the actuator of $150 \mathrm{kN}$ load capacity and $200 \mathrm{~mm}$ stroke. In the right span, the load $\left(F_{123}\right)$ was applied with an actuator of $100 \mathrm{kN}$ and $200 \mathrm{~mm}$ stroke, and the corresponding force was measured using a load cell of $\pm 250 \mathrm{kN}$ and accuracy of $\pm 0.05 \%$ (designated as Ctrl_2). To monitor the reaction forces, load cells were installed in two supports. One load cell (AEP_200) was positioned at the central support (nonadjustable support), placed between the reaction steel frame and the slab's support device. 
The other load cell (MIC_200) was positioned in-between the reaction steel frame and the apparatus of the adjustable right support of the slab. These cells have a load capacity of $200 \mathrm{kN}$ and accuracy of $\pm 0.05 \%$. Unfortunately, due to a deficient functioning of the data acquisition device, the signals in these last two load cells were not registered in the test of the SL15-HS reference slab.

To monitor the strain variation in the steel bars, concrete and CFRP laminates, the arrangements of strain gauges (SGs) represented in Figs. 3 to 5 were adopted. Eleven SGs were installed in steel bars, seven of them in steel bars at top surface in the hogging region (SG1 to SG7), and the other four in steel bars at bottom surface in the sagging regions (SG8 to SG11). Six SGs were applied at the concrete surface in the compression regions (SG12 to SG17). Finally, three SGs were installed along one CFRP laminate in both sagging regions (SG18 to SG20 and SG21 to SG23), and three SGs (SG24 to SG26) were bonded along one CFRP laminate in the hogging region.

\subsection{Materials properties}

Tables 2 and 3 include the values obtained from the experimental tests for the main properties of the materials used in the present research program. The compressive strength and the Young's modulus of the concrete were determined according to LNEC-E397 [28]. To characterize the steel bars, uniaxial tensile tests were conducted according to the standard procedures of ASTM A370 [29]. Unidirectional pultruded CFRP laminates were used in this study and their tensile behavior was assessed by performing uniaxial tensile tests carried out according to ISO 527-1 [30] and ISO 527-5 [31] recommendations. For the characterization of the tensile behavior of the epoxy adhesive, uniaxial tensile tests were performed complying with the procedures outlined in ISO 527-2 [32]. For the elasticity modulus and tensile strength of the adhesive values of, respectively, $7.91 \mathrm{GPa}(5.16 \%)$ and $19.19 \mathrm{MPa}$ $(15.59 \%)$ were obtained, where the values between round brackets correspond to the coefficient of variation.

\subsection{Strengthening system}

The first step of the NSM strengthening process consisted in opening the slits for the installation of the CFRP laminates, by using a conventional diamond saw cut machine. The slits had a width that varied between 4.5 and $4.6 \mathrm{~mm}$ and a depth of $15 \mathrm{~mm}$ or $27 \mathrm{~mm}$, depending on the depth of the cross section of the used CFRP laminate, 10 or $20 \mathrm{~mm}$, respectively. To eliminate the dust resultant from the sawing process, the slits were cleaned using compressed air before bonding the laminates to the concrete into the slits. The CFRP laminates were cleaned with acetone to remove any possible dirt. Finally, the slits were filled with the epoxy adhesive using a spatula, and the CFRP laminates were introduced into the slits. 


\section{RESULTS AND ANALYSIS}

The average load $\left(F=\left(F_{522}+F_{123}\right) / 2\right)$ versus deflection curves of the tested slab strips are presented in Fig. 7. This figure reveales that the adopted NSM HS strengthening configurations have provided a significant increase of the load carrying during the second phase of the test loading process.

For all the slabs, flexural cracks were first observed at a $F$ of about $6 \mathrm{kN}$. Four phases occurred during each test in the following sequence: (a) the uncracked elastic response; (b) crack propagation in the hogging and sagging regions with steel bars in elastic stage; (c) yielding of the steel reinforcement in the hogging region and crack propagation in the sagging regions with steel bars in elastic stage; and (d) yielding of the steel reinforcement in the sagging regions. Fig. 7 also depicts the cracking load $\left(F_{c r}\right)$ and the load at the formation of the plastic hinge in the hogging $\left(F_{y}^{H}\right)$ and sagging $\left(F_{y}^{S}\right)$ regions. The phases registered for the reference slab strips of the SL15 series are indicated in Fig. 7a, but similar behavior was obtained for all tested slab strips.

\section{Reference slabs:}

As expected, the unstrengthened control slab strips behaved in a perfectly plastic manner in the post-yielding phase (after the formation of plastic hinges in the hogging and sagging regions), whereas the strengthened slab strips exhibited continuous hardening up to failure. The reference slabs failed in bending, i.e. by yielding of internal reinforcements, with extensive concrete cracking in both hogging and sagging regions, followed by concrete crushing in compression parts, as shown in Figs. 8 and 9.

\section{$\underline{\text { H series: }}$}

The slab strips strengthened to increase in 25\% the loading carrying capacity (SL15S25-H, SL30S25-H and SL45S25-H) were also governed by flexural failure: yielding of the internal steel reinforcements followed by the concrete crushing and CFRP rupture after high deflection values.

In the slab strips strengthened to increase in 50\% the loading carrying capacity, all slab strips (SL15S50-H, SL30S50-H and SL45S50-H) failed in shear, by intermediate shear crack mechanism with extensive cracking in the tension flange. In these strengthened slabs, neither the CFRP laminate cover separation nor the full debond of the CFRP laminates failure mode has occurred (Fig. 8).

As previously mentioned, two arrangements of CFRP laminates were applied in the hogging region with the purpose of increasing the resisting bending moment of the slab cross section at the intermediate support (negative bending moment) and, consequently, the load carrying capacity of the reference slab in $25 \%$ and $50 \%$. It is verified that, 
though the target increase in the negative resisting bending moment has been exceeded in the strengthened slabs, an average increase of $8 \%$ and $16 \%$ was obtained for the load carrying capacity of these strengthened slabs

\section{$\underline{\text { HS Series }}$}

The first phase of the loading process of the SL15s25-HS slab strip ended at a deflection of $5.40 \mathrm{~mm}$, when a load of $14 \mathrm{kN}$ was recorded. This slab strip failed by the detachment of the top concrete cover that includes the laminates in the hogging region.

At the end of the first phase of the test of SL30s25-HS slab strip a deflection of $5.80 \mathrm{~mm}$ and a load $17 \mathrm{kN}$ were registered. From the analysis of the results of Table 5 and 6, it can be noted that, for a concrete compressive strain of $3.5 \%$ and at the maximum load, the increase of the load carrying capacity provided by the strengthening system was of about $29 \%$ and $52.48 \%$, respectively, which exceeded the target value. This slab strip failed by the detachment of the top concrete cover that included the laminates in the hogging region (Fig. 10).

The SL30s50-HS failed by the detachment of the bottom concrete cover that includes the laminates in sagging region (left span, Fig. 11). In the first phase of the test, the strengthened slab strip was loaded up to a deflection of 5.80 $\mathrm{mm}$, which corresponds to a load of $14 \mathrm{kN}$. From the analysis of the results presented in Table 5 and 6 , it can be noted that, for a concrete compressive strain of $3.5 \%$ and at the maximum load, the increase of the load carrying capacity provided by the strengthening system was about $49 \%$ and $68.07 \%$, which attained the target value.

The SL45s25-HS failed by shear, followed by the rupture of the CFRP laminates, in the intermediate support (Figs. 9 and 10). In the first phase of the test this slab strip was loaded up to a deflection of $5.70 \mathrm{~mm}$, which corresponds to a load of $16.7 \mathrm{kN}$. From the analysis of the results shown in Table 5, it can be noted that, for a compressive strain of 3.5\%o, the increase of the load carrying capacity provided by the strengthening system was about the target value $(24.42 \%)$. At $F_{\max }$, an increase of the load carrying capacity of $28.55 \%$ was obtained.

The SL45s50-HS also failed by shear, followed by the rupture of the CFRP laminates in the intermediate support, followed by the detachment of the top concrete cover that includes the laminates in the hogging region (Fig. 10). In the first phase of the test this slab strip was loaded up to a deflection of $5.70 \mathrm{~mm}$, which corresponds to a load of $17.10 \mathrm{kN}$. From the analysis of the results, it can be noted that, for a compressive strain of $3.5 \%$, the increase of the load carrying capacity provided by the strengthening system was about $37.24 \%$. At $F_{\max }$, an increase of the load carrying capacity of $53.13 \%$ was obtained. Table 4 summarizes the results obtained experimentally for two scenarios: when a plastic hinge formed at the hogging region (superscript $\mathrm{H}$ ); when a plastic hinge formed at the sagging regions (superscript $\mathrm{S}$ ). Plastic hinge was assumed formed when the steel tensile reinforcement attained its yield strain $\left(\varepsilon_{s y}\right)$. In this table, $F_{y}^{H}$ and $F_{y}^{S}$ are the average loads $\left(F=\left(F_{522}+F_{123}\right) / 2\right.$ ) at the formation of the plastic hinge at hogging and sagging regions, 
respectively, $u_{y}^{H}$ and $u_{y}^{S}$ are the average deflections for $F_{y}^{H}$ and $F_{y}^{S}$, respectively, $\varepsilon_{c}^{H}$ and $\varepsilon_{c}^{S}$ are the maximum concrete strains registered at $\mathrm{H}$ and $\mathrm{S}$ regions, $\varepsilon_{s}^{H}$ and $\varepsilon_{s}^{S}$ are the maximum strains in steel bars at $\mathrm{H}$ and $\mathrm{S}$ regions, respectively, $\varepsilon_{f}^{H}$ and $\varepsilon_{f}^{S}$ are the maximum strains in the CFRP laminates at the hogging and sagging regions, and, finally, $\Delta F_{y}^{H}$ and $\Delta F_{y}^{S}$ are the increase of the loading carrying capacity when a plastic hinge was formed at the $\mathrm{H}$ and S regions. Unfortunately, for the SL15-HS, due to a deficient functioning of the data acquisition system, the forces in the AEP_200 and MIC_200 load cells were not recorded, thus impeding the moment redistribution calculation. Table 5 presents the relevant results when the maximum concrete compressive strain attained $3.5 \%$ o (assumed to be the concrete crushing strain) in the hogging and sagging regions (symbols with subscript " $c u$ "). In this table, $\eta$ is the moment redistribution percentage and $I R$ represents the increase of load carrying capacity provided by the strengthening technique, calculated according to the following equation:

$I R=\frac{F_{c u}^{C F R P}-F_{c u}^{R E F}}{F_{c u}^{C F R P}} 100$

where $F_{c u}^{C F R P}$ and $F_{c u}^{R E F}$ are the loads of, respectively, the strengthened and reference slabs when the maximum compressive strain in the sagging regions attained $3.5 \%$. Finally, Table 6 summarizes the results obtained when the maximum load $\left(F_{\max }\right)$ was attained. In this table, $F_{\max }$ and $u_{F_{\max }}$ are the average maximum loads ( $\left.F=\left(F_{522}+F_{123}\right) / 2\right)$ and the average deflections for $F_{\max }$, respectively, $\varepsilon_{c, \text { max }, F_{\max }}^{H}$ and $\varepsilon_{c, \text { max }, F_{\max }}^{S}$ are the maximum concrete strains registered at $\mathrm{H}$ and $\mathrm{S}$ regions, $\varepsilon_{s, \max , F_{\max }}^{H}$ and $\varepsilon_{s, \max , F_{\max }}^{S}$ are the maximum strains in steel bars at $\mathrm{H}$ and $\mathrm{S}$ regions, respectively, $\varepsilon_{f, \max , F_{\max }}^{H}$ and $\varepsilon_{f, \max , F_{\max }}^{S}$ are the maximum strains in the CFRP laminates at the hogging and sagging regions, $I R$ represents the increase of load carrying capacity provided by the strengthening technique and, finally, $\eta$ is the moment redistribution percentage.

From the analysis of the results included in Tables 4 to 6 and represented in Fig. 7 the following observations can be outlined for the H Series:

(i) After concrete crack initiation, the slab stiffness decreased significantly, but the elasto-cracked stiffness was almost maintained up to the formation of the plastic hinge in the hogging region;

(ii) Up to the formation of the plastic hinge in the hogging region the tensile strains in the laminates are far below their ultimate tensile strain. At concrete crushing the maximum tensile strain in the laminates attained $67 \%$ of their ultimate tensile strain for the SL45s50-H slab strip, but the increase in the load carrying capacity was limited to $9 \%$; 
(iii) The force-deflection relationship evidences that, up to the formation of the plastic hinge in the hogging region, the laminates had a marginal contribute for the slab's load carrying capacity. It is also observed that the moment redistribution capability is negatively affected when the percentage of CFRP laminates increases in the hogging region. The justifications for this behavior are detailed elsewhere [34].

For the HS series the results indicated in Tables 4 to 6 can be point out the following conclusions:

(i) Up to the formation of the plastic hinge in the hogging region the strains in the laminates have ranged from $0.88 \%$ o to $1.94 \%$, which justifies the relative low contribution of the laminates to the load carrying capacity up to this load level. At the formation of the plastic hinge in the sagging regions the strain in the laminates have increased, having been in the range $2.69 \%$ o to $9.66 \%$. However, at concrete crushing in the sagging regions, the maximum strain in the CFRP laminates has varied between $4.03 \%$ and $11.95 \%$, which is $23 \%$ to $67 \%$ of the CFRP laminate ultimate strain.

(ii) The deflection at $F_{y}^{S}, u_{y}^{S}$, was not significantly affected by the presence of the CFRP laminates, which means that ductility is preserved.

(iii) The contribution of the CFRP laminates for the slab's maximum load carrying capacity was limited by the occurrence of concrete crushing, the detachment of the concrete cover layer that includes the laminates or the shear capacity of the slabs.

(iv) At the maximum applied load, high values of moment redistribution percentages were obtained.

Fig. 12 depicts the relationship between the average applied load and the moment redistribution percentage for the tested slabs. In the beginning of the tests some instability were observed due to the adjustment of supports until the crack propagation in the hogging and sagging regions with steel bars in elastic stage. So, the obtained curves before the cracking load were removed from the graphs. Between cracking load $\left(F_{c r}\right)$ and the formation of the plastic hinge in the hogging region $\left(F_{y}^{H}\right)$ no clear tendency is observed for the moment redistribution, but after $F_{y}^{H}$ the $\eta$ has a tendency to increase up to the formation of the plastic hinge in the sagging regions $\left(F_{y}^{S}\right)$. When the plastic hinge formed in the hogging region, the consequent loss of stiffness forced a migration of moments from the hogging to the sagging regions, resulting an increase of $\eta$. The graphs of Fig. 12 also show that, for the $H$ series, $\eta$ has decreased with the increase of the percentage of CFRP laminates. For a compressive strain of $3.5 \%$ in the concrete surface at loaded sections, the following values of $\eta$ were obtained for the H Series: $0.92 \%,-10.74 \%,-25.32 \%$ for SL15-H, SL15s25-H, SL15s50-H; 26.37\%, 15.40\%, 5.01\% for SL30-H, SL30s25-H, SL30s50-H; 43.25\%, 35.68\%, 22.45\% for SL45-H, SL45s25-H, SL45s50-H. $\eta$ were obtained at the maximum load: $7.85 \%,-20.40 \%,-27.64 \%$ for 
SL15-H, SL15s25-H, SL15s50-H; 27.71\%, 6.36\%, -2.42\% for SL30-H, SL30s25-H, SL30s50-H; 43.62\%, 32.58\%, $16.73 \%$ for SL45-H, SL45s25-H, SL45s50-H.

Adopting a flexural strengthening strategy composed of CFRP laminates applied in both hogging and sagging regions, the moment redistribution capacity was not significantly affected by the presence of the laminates and, in some cases, higher values were obtained in comparison to the reference slab strips. For the HS series, the following values of $\eta$ were obtained: $6.20 \%$ for SL15s25-HS; $19.94 \%, 21.45 \%, 29.89 \%$ for SL30-HS, SL30s25-HS, SL30s50-HS; 39.21\%, 41.69\%, 44.10\% for SL45-HS, SL45s25-HS, SL45s50-HS. Finally, the following values of $\eta$ were obtained at the maximum load: $8.85 \%$ for SL15s25-HS; 19.69\%, 26.58\%, 31.67\% for SL30-HS, SL30s25HS, SL30s50-HS; 38.93\%, 37.66\%, 47.04\% for SL45-HS, SL45s25-HS, SL45s50-HS.

Figs. 13 and 14 present the relationship between the bending moments at the critical sections (sagging and hogging regions) and the applied load $(F-M)$. The bending moments were calculated from the forces recorded in the load cell located in the lateral support (MIC_200) and in one of the actuators $\left(F_{123}\right)$, see Fig. 1. These figures also include the relationship between bending moments and applied load if linear-elastic behavior is assumed for the slab (lines without markers). Additionally, Table 7 presents the force values at $F_{123}$ and MIC_200 and the corresponding bending moments at the hogging and sagging regions $\left(M^{-}\right.$and $\left.M^{+}\right)$for the three relevant loading stages: yield initiation at the hogging and sagging regions $\left(F_{y}^{H}\right.$ and $F_{y}^{S}$, respectively), and at the maximum load, $F_{\max }$. From Figures 13 and 14 it is verified that the deviation from the linear-elastic approach for the $F-M$ response is only relevant after yield initiation in the hogging region, with a migration of the negative bending moments from the hogging region to the positive bending moments in the sagging regions. As expected, this migration level has increased from SL15 to SL45 series in both H and HS groups. However, in each series of the H group this migration level was negatively affected with the increase of the percentage of CFRP in the hogging region, while in the series of HS group this effect was not significant.

\section{CONCLUSIONS}

In this work an experimental program with statically indeterminate (two equal spans) reinforced concrete (RC) slab strips was carried out to assess the effectiveness of the Near Surface Mounted (NSM) technique for the increase of the load carrying capacity and moment redistribution capability. Carbon fiber reinforced polymer (CFRP) laminates of rectangular cross section were used. The experimental program was composed of seventeen $120 \times 375 \times 5875 \mathrm{~mm}^{3}$ RC slab strips. Six of them were unstrengthened RC slabs forming a control set (SL15-H/HS, SL30-H/HS and 
SL45-H/HS), and the other eleven slabs were strengthened with CFRP strips according to the NSM technique (SL15s25-H, SL15s50-H/HS, SL30s25-H/HS, SL30s50-H/HS, SL45s25-H/HS and SL45s50-H/HS), divided in two different strengthening arrangements: CFRP laminates applied only in the hogging region (H Series) or in both sagging and hogging regions (HS Series). The amount and disposition of the steel bars were designed to assure a moment redistribution percentages of $15 \%, 30 \%$ and $45 \%$. The NSM CFRP systems applied in the flexurally strengthened RC slabs were designed to increase in $25 \%$ and $50 \%$ the load carrying capacity of the reference slab. From the obtained results the following conclusions can be pointed out:

1) For the H Series, when the concrete compressive strain attained 3.5\% in the hogging region, the increase of slab's load carrying capacity $(\Delta \mathrm{F})$ varied between $2.87 \%$ and $19.79 \%$, while an increase of $\Delta \mathrm{F}$ between $4.03 \%$ and $19.29 \%$ was registered when a concrete compressive strain of $3.5 \%$ was recorded in the sagging regions. According to the obtained results, the strengthening configurations composed by laminates only applied in the hogging region did not attain the target increase of the load carrying capacity.

2) For the HS series, when the concrete compressive strain attained 3.5\% in the hogging region, the increase of $\Delta \mathrm{F}$ has varied between $28.54 \%$ and $49.77 \%$, while an increase of $\Delta \mathrm{F}$ between 29.84 and $49.44 \%$ was registered when a concrete compressive strain of $3.5 \%$ was recorded in the sagging regions. When applying CFRP laminates in both sagging and hogging regions (HS series), the target increase of the load carrying capacity was attained.

3) Moment redistribution percentage $(\eta)$ lower than the predicted one was determined in the slabs strengthened with CFRP laminates in the hogging region $(H)$. For this strengthening configuration the $\eta$ has decreased with the increase of the CFRP percentage. However, adopting a flexural strengthening strategy composed of CFRP laminates applied in both hogging and sagging regions, the moment redistribution capacity was not significantly affected. For this configuration of NSM laminates, the flexural strengthening performance was limited by the detachment of the concrete cover that includes the laminates or by the formation of a shear crack in the hogging region.

\section{ACKNOWLEDGEMENTS}

The study reported in this paper forms a part of the research program "PRELAMI - Performance of reinforced concrete structures strengthened in flexural with an innovative system using prestressed NSM CFRP laminates." supported by FCT, PTDC/ECM/114945/2009. The writers acknowledge the support also provided by the S\&P, Casais and Artecanter Companies. The first author acknowledges the financial support of FCT, PhD Grant number SFRH/BD/69818/2010. The second Author wishes to acknowledge the support provided by FCT, by means of the SFRH/BSAB/818/2008 and SFRH/BSAB/913/2009 sabbatical grants. 


\section{REFERENCES}

[1] Aiello, M.A., Valente, L. and Rizzo, A. Moment Redistribution in continuous reinforced concrete beams strengthened with carbon-fiber-reinforced polymer laminates. Mechanics of Composite Materials, 2007; 43(5): 667686.

[2] Ashour, A. F., El-Refaie, S.A. and Garrity, S.W. Flexural strengthening of RC continuous beams using CFRP laminates. Cement \& Concrete Composites, 2004; 26(7): 765 - 775.

[3] Park, S. M. and Oehlers, D. J. Details of tests on steel and FRP plated continuous reinforced concrete beams. School of Civil and Environmental Engineering, University of Adelaide, Research Report R170, 34 pp; 2000.

[4 ]El-Refaie, S. A., Ashour, A. F. and Garrity, S. W. Sagging and hogging strengthening of continuous reinforced concrete beams using CFRP sheets. ACI Structural Journal, 2003; 100(4): 446-453.

[5] ACI Committee 440. Guide for the design and construction of externally bonded FRP systems for strengthening concrete structures. ACI440.2R-08, Reported by ACI Committee 440, American Concrete Institute, Farmington Hills, Mich, 80 pp; 2008.

[6] FIB - Bulletin 14. Externally bonded FRP reinforcement for RC structures. Technical report by Task Group 9.3 FRP, 130 pp; 2001.

[7] Barros, J.A.O., Kotynia, R. Possibilities and challenges of NSM for the flexural strengthening of RC structures. Fourth International Conference on FRP Composites in Civil Engineering (CICE2008), Zurich, Switzerland, 22-24 July; 2008.

[8] Barros, J.A.O., Dias, S.J.E., Lima, J.L.T. Efficacy of CFRP-based techniques for the flexural and shear strengthening of concrete beams. Journal Cement and Concrete Composites, 2007; 29(3): 203-217.

[9] Barros, J.A.O., Fortes, A.S. Flexural strengthening of concrete beams with CFRP laminates bonded into slits." Journal Cement and Concrete Composites, 2005; 27(4): 471-480.

[10] De Lorenzis, L., A. Nanni, and A. La Tegola. Strengthening of Reinforced Concrete Structures with Near Surface Mounted FRP Rods." Bibl. International Meeting on Composite Materials, PLAST 2000, Milan, Italy, May 9-11, 2000.

[11] Carolin, A. Carbon fibre reinforced polymers for strengthening of structural elements. Doctoral Thesis, Lulea Univ. of Technology, Lulea, Sweden; 2003.

[12] El-Hacha, R., Rizkalla, S.H. Near-surface-mounted fiber-reinforced polymer reinforcements for flexural strengthening of concrete structures. ACI Structural Journal, 2004; 101(5): 717-726.

[13] Liu, I.S.T., Oehlers, D.J. and Seracino, R. Tests on the ductility of reinforced concrete beams retrofitted with FRP and steel near-surface mounted plates. Journal of Composites for Construction, 2006; 10(2): 106-114.

[14] Nordin, H. Flexural strengthening of concrete structures with prestressed near surface mounted CFRP rods." Licentiate Thesis, Lulea Univ. of Technology, Lulea, Sweden; 2003.

[15] Bonaldo, E., Barros, J.A.O. and Lourenço, P.B. Efficient strengthening technique to increase the flexural resistance of existing RC slabs. Journal of Composites for Construction, 2008; 12(2): 149-159.

[16] Barros, J.A.O., Dias, S.J.E. Near surface mounted CFRP laminates for shear strengthening of concrete beams." Cement \& Concrete Composites, 2006; 28(3): 276-292.

[17] Dias, S.J.E., Barros, J.A.O. Shear strengthening of T cross section reinforced concrete beams by near surface mounted technique. Journal Composites for Construction, 2008; 12(3): 300-311.

[18] Dias, S.J.E., Barros, J.A.O. Performance of reinforced concrete T beams strengthened in shear with NSM CFRP laminates. Engineering Structures, 2010; 32(2): 373-384. 
[19] Islam, A.K.M.A. Effective methods of using CFRP bars in shear strengthening of concrete girders. Engineering Structures, 2009; 31(3): 709-714.

[20] Grace, N.F., Ragheb, W.F. and Abdel-Sayed, G. Strengthening of Cantilever and Continuous Beams using New Triaxially Braided Ductile Fabric. ACI Structural Journal, 2004; 101: 237-244.

[21] Akbarzadeh Bengar, H., Maghsoudi, A.A. Experimental investigations and verification of debonding strain of RHSC continuous beams strengthened in flexure with externally bonded FRPs. Materials and Structures Journal, $10.1617 / \mathrm{s} 11527-009-9550-7$.

[22] Vasseur, L. Nonlinear behavior of continuous concrete beams strengthened with Externally Bonded FRP Reinforcement. Doctoral Thesis, Ghent University, Ghent, Belgium; 2009.

[23] Lui, I.S.T. Intermediate crack debonding of plated reinforced concrete beams." PhD Thesis, School of Civil and Environmental Engineering, The University of Adelaide, Adelaide, Australia; 2005.

[24] Bonaldo, E. Composite materials and discrete steel fibres for the strengthening of thin concrete structures" PhD Thesis, University of Minho, Guimarães, Portugal; 2008.

[25] CEB-FIP Model Code 1990. Design Code. Thomas Telford, Lausanne, Switzerland; 1993.

[26] ACI Committee 318. Building code requirements for structural concrete (ACI 318-08) and Commentary. ACI 318R-08, Reported by ACI Committee 318, American Concrete Institute, Farmington Hills, Mich, 471 pp; 2008.

[27] Bianco, V., Barros, J.A.O., Monti, G. New approach for modeling the contribution of NSM FRP strips for shear strengthening of RC beams", ASCE Composites for Construction Journal, 2010; 14(1): 36-48.

[28] LNEC-E397. Concrete - Assessment of the elasticity modulus under uniaxial compression. Laboratório Nacional de Engenharia Civil (in Portuguese); 1993.

[29] ASTM A370. Standard test methods and definitions for mechanical testing of steel products." American Society for Testing and Materials, 52pp; 2002.

[30] ISO 527-1. Plastics - Determination of tensile properties - Part 1: General principles." International Organization for Standardization (ISO), Genèva, Switzerland, 9 pp; 1993.

[31] ISO 527-5. Plastics - Determination of tensile properties - Part 5: Test conditions for unidirectional fibrereinforced plastic composites." International Organization for Standardization (ISO), Genèva, Switzerland, 9 pp; 1993.

[32] ISO 527-2. Plastics - Determination of Tensile Properties - Part 2: Test Conditions for Moulding and Extrusion Plastics. International Organization for Standardization (ISO), Geneva, Switzerland, 5 pp; 1993.

[33] Dalfré, G., Barros. Flexural Strengthening of RC Continuous Slab Strips Using NSM CFRP Laminates. Advances in Structural Engineering, 2011; 14 (6): 1223:1245.

[34] Dalfré, G.M., Barros, J., Alves, S. Analysis of one-way RC slabs flexural strengthened with NSM CFRP Laminates. Technical Report 10-DEC/E-15, Dep. Civil Eng., School Eng. University of Minho; 2010. 


\section{TABLE CAPTIONS}

Table 1. Geometry, reinforcement and strengthening details of the cross sections of the slab strips Table 2. Properties of concrete

Table 3. Summary of the properties of steel reinforcement and CFRP laminates

Table 4. Main results obtained in the experimental program at the formation of the plastic hinges

Table 5. Main results obtained in the experimental program at the concrete crushing initiation

Table 6. Main results obtained in the experimental program at the average maximum load

Table 7. Relevant experimental results at three levels of loading: $F_{y}^{H}, F_{y}^{S}$ and $F_{\max }$. 
Table 1. Geometry, reinforcement and strengthening details of the cross sections of the slab strips

\begin{tabular}{|c|c|c|c|c|c|c|c|c|}
\hline ID & $\eta$ & $\begin{array}{l}\text { Increase of the } \\
\text { loading carrying } \\
\text { capacity }\end{array}$ & $\begin{array}{l}\text { Cross-Section } \\
\quad \mathrm{S}_{1}-\mathrm{S}_{1}\end{array}$ & $\begin{array}{l}\text { Number of CFRP } \\
\text { laminates at } S\end{array}$ & $\begin{array}{r}\rho_{l, e q}^{S} \\
(\%)\end{array}$ & $\begin{array}{l}\text { Cross-Section } \\
\quad \mathrm{S}_{2}-\mathrm{S}_{2}\end{array}$ & $\begin{array}{c}\text { Number of CFRP } \\
\text { Laminates at } \mathrm{H}\end{array}$ & $\begin{array}{r}\rho_{l, e q}^{H} \\
(\%)\end{array}$ \\
\hline \multirow{9}{*}{ 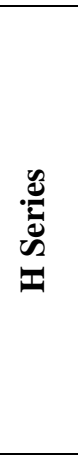 } & \multirow{3}{*}{$15 \%$} & $0 \%$ & \multirow{3}{*}{$\begin{array}{c}A_{s}^{\prime}=2 \phi 12 m m \\
A_{s}=4 \phi 12 m m+3 \phi 8 m m\end{array}$} & 0 & 1.71 & \multirow{3}{*}{$\begin{array}{c}\mathrm{A}_{\mathrm{s}}=5 \phi 12 \mathrm{~mm} \\
\mathrm{~A}_{\mathrm{s}}^{\prime}=2 \phi 12 \mathrm{~mm}+1 \phi 8 \mathrm{~mm}\end{array}$} & 0 & 1.60 \\
\hline & & $25 \%$ & & 0 & 1.71 & & $3 \times 1.4 \times 10 \mathrm{~mm}^{2}$ & 1.68 \\
\hline & & $50 \%$ & & 0 & 1.71 & & $7 \times 1.4 \times 10 \mathrm{~mm}^{2}$ & 1.80 \\
\hline & \multirow{3}{*}{$30 \%$} & $0 \%$ & \multirow{3}{*}{$\begin{array}{c}A_{\mathrm{s}}^{\prime}=2 \phi 12 \mathrm{~mm} \\
\mathrm{~A}_{\mathrm{s}}=3 \phi 12 \mathrm{~mm}+4 \phi 10 \mathrm{~mm}\end{array}$} & 0 & 1.85 & \multirow{3}{*}{$\begin{array}{c}A_{s}=4 \phi 12 \mathrm{~mm} \\
A_{s}^{\prime}=2 \phi 10 m m+1 \phi 12 m m\end{array}$} & 0 & 1.28 \\
\hline & & $25 \%$ & & 0 & 1.85 & & $2 \times 1.4 \times 10 \mathrm{~mm}^{2}$ & 1.34 \\
\hline & & $50 \%$ & & 0 & 1.85 & & $5 \times 1.4 \times 10 \mathrm{~mm}^{2}$ & 1.42 \\
\hline & \multirow{3}{*}{$45 \%$} & $0 \%$ & \multirow{3}{*}{$\begin{array}{c}A_{\mathrm{s}}^{\prime}=2 \phi 10 \mathrm{~mm} \\
A_{\mathrm{s}}=6 \phi 12 \mathrm{~mm}+1 \phi 8 \mathrm{~mm}\end{array}$} & 0 & 2.07 & \multirow{3}{*}{$\begin{array}{l}\mathrm{A}_{\mathrm{s}}=3 \phi 10 \mathrm{~mm}+2 \phi 8 \mathrm{~mm} \\
\mathrm{~A}_{\mathrm{s}}^{\prime}=2 \phi 12 \mathrm{~mm}+1 \phi 8 \mathrm{~mm}\end{array}$} & 0 & 0.95 \\
\hline & & $25 \%$ & & 0 & 2.07 & & $1 \times 1.4 \times 10 \mathrm{~mm}^{2}$ & 0.98 \\
\hline & & $50 \%$ & & 0 & 2.07 & & $3 \times 1.4 \times 10 \mathrm{~mm}^{2}$ & 1.03 \\
\hline \multirow{8}{*}{ 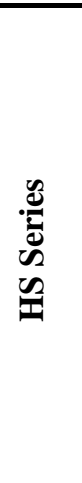 } & \multirow[b]{2}{*}{$15 \%$} & $0 \%$ & \multirow{2}{*}{$\begin{array}{c}A_{s}^{\prime}=2 \phi 12 \mathrm{~mm} \\
A_{s}=4 \phi 12 \mathrm{~mm}+3 \phi 8 \mathrm{~mm}\end{array}$} & 0 & 1.71 & \multirow{2}{*}{$\begin{array}{c}A_{s}=5 \phi 12 \mathrm{~mm} \\
A_{s}^{\prime}=2 \phi 12 \mathrm{~mm}+1 \phi 8 \mathrm{~mm}\end{array}$} & 0 & 1.60 \\
\hline & & $25 \%$ & & $\begin{array}{c}1 \times 1.4 \times 10 \mathrm{~mm}^{2}+ \\
2 \times 1.4 \times 20 \mathrm{~mm}^{2}\end{array}$ & 1.85 & & $4 \times 1.4 \times 20 \mathrm{~mm}^{2}$ & 1.83 \\
\hline & \multirow{3}{*}{$30 \%$} & $0 \%$ & \multirow{3}{*}{$\begin{array}{c}\mathrm{A}_{\mathrm{s}}{ }^{\prime}=2 \phi 12 \mathrm{~mm} \\
\mathrm{~A}_{\mathrm{s}}=3 \phi 12 \mathrm{~mm}+4 \phi 10 \mathrm{~mm}\end{array}$} & 0 & 1.85 & \multirow{3}{*}{$\begin{array}{c}A_{s}=4 \phi 12 \mathrm{~mm} \\
A_{s}^{\prime}=2 \phi 10 \mathrm{~mm}+1 \phi 12 \mathrm{~mm}\end{array}$} & 0 & 1.28 \\
\hline & & $25 \%$ & & $\begin{array}{c}2 \times 1.4 \times 10 \mathrm{~mm}^{2}+ \\
2 \times 1.4 \times 20 \mathrm{~mm}^{2}\end{array}$ & 2.02 & & $2 \times 1.4 \times 20 \mathrm{~mm}^{2}$ & 1.39 \\
\hline & & $50 \%$ & & $\begin{array}{c}1 \times 1.4 \times 10 \mathrm{~mm}^{2}+ \\
6 \times 1.4 \times 20 \mathrm{~mm}^{2}\end{array}$ & 2.22 & & $3 \times 1.4 \times 20 \mathrm{~mm}^{2}$ & 1.45 \\
\hline & \multirow{3}{*}{$45 \%$} & $0 \%$ & \multirow{3}{*}{$\begin{array}{c}A_{s}^{\prime}=2 \phi 10 \mathrm{~mm} \\
A_{s}=6 \phi 12 \mathrm{~mm}+1 \phi 8 \mathrm{~mm}\end{array}$} & 0 & 2.07 & \multirow{3}{*}{$\begin{array}{l}\mathrm{A}_{\mathrm{s}}=3 \phi 10 \mathrm{~mm}+2 \phi 8 \mathrm{~mm} \\
\mathrm{~A}_{\mathrm{s}}^{\prime}=2 \phi 12 \mathrm{~mm}+1 \phi 8 \mathrm{~mm}\end{array}$} & 0 & 0.95 \\
\hline & & $25 \%$ & & $2 \times 1.4 \times 20 \mathrm{~mm}^{2}$ & 2.20 & & $2 \times 1.4 \times 10 \mathrm{~mm}^{2}$ & 1.00 \\
\hline & & $50 \%$ & & $6 \times 1.4 \times 20 \mathrm{~mm}^{2}$ & 2.43 & & $2 \times 1.4 \times 20 \mathrm{~mm}^{2}$ & 1.06 \\
\hline
\end{tabular}


Table 2. Properties of concrete

\begin{tabular}{|c|c|c|c|}
\hline \multirow{3}{*}{$\begin{array}{c}\text { Slab strip } \\
\text { Series }\end{array}$} & \multicolumn{3}{|c|}{ Property } \\
\hline & \multicolumn{2}{|c|}{$f_{c m}(\mathrm{MPa})$} & $E_{c}(\mathrm{GPa})$ \\
\hline & H series & HS series & HS series \\
\hline SL15 & $40.07(0.59)$ & $26.37(1.06)$ & $24.29(1.18)$ \\
\hline SL30 & $35.99(0.51)$ & $28.40(1.61)$ & $29.83(0.29)$ \\
\hline SL45 & $41.41(0.22)$ & $42.38(0.03)$ & $28.32(1.54)$ \\
\hline
\end{tabular}

(value $)=$ Standard deviation in $\mathrm{MPa}, f_{c m}=$ mean cylinder compressive strength, $E_{c}=$ modulus of elasticity 
Table 3. Summary of the properties of steel reinforcement and CFRP laminates

\begin{tabular}{|c|c|c|c|c|c|c|c|c|}
\hline \multicolumn{5}{|c|}{ Steel reinforcement } & \multicolumn{4}{|c|}{ CFRP Laminate } \\
\hline $\begin{array}{l}\text { Steel bar } \\
\text { diameter } \\
(\mathrm{mm})\end{array}$ & $\begin{array}{l}\text { Modulus of } \\
\text { elasticity } \\
(\mathrm{GPa})\end{array}$ & $\begin{array}{l}\text { Yield stress } \\
(0.2 \%)^{\mathrm{a}} \\
(\mathrm{MPa})\end{array}$ & $\begin{array}{l}\text { Strain } \\
\text { at yield } \\
\text { stress }^{b}\end{array}$ & $\begin{array}{c}\text { Tensile } \\
\text { strength } \\
(\mathrm{MPa})\end{array}$ & $\begin{array}{l}\text { Height of the } \\
\text { cross section } \\
\quad(\mathrm{mm})\end{array}$ & $\begin{array}{l}\text { Ultimate } \\
\text { tensile } \\
\text { stress } \\
(\mathrm{MPa})\end{array}$ & $\begin{array}{l}\text { Ultimate } \\
\text { tensile } \\
\text { strain } \\
(\% o)\end{array}$ & $\begin{array}{l}\text { Modulus } \\
\text { of } \\
\text { elasticity } \\
\text { (GPa) }\end{array}$ \\
\hline 8 & $\begin{array}{c}200.80 \\
(2.33 \%)\end{array}$ & $\begin{array}{c}421.35 \\
(0.53 \%)\end{array}$ & $\begin{array}{c}0.0023 \\
(2.65 \%)\end{array}$ & $\begin{array}{c}578.75 \\
(0.36 \%)\end{array}$ & 10 & $\begin{array}{l}2867.63 \\
(3.07 \%)\end{array}$ & $\begin{array}{c}17.67 \\
(3.04 \%)\end{array}$ & $\begin{array}{c}159.30 \\
(3.15 \%)\end{array}$ \\
\hline 10 & $\begin{array}{c}178.24 \\
(2.48 \%) \\
\end{array}$ & $\begin{array}{c}446.95 \\
(3.25 \%) \\
\end{array}$ & $\begin{array}{c}0.0027 \\
(0.45 \%)\end{array}$ & $\begin{array}{c}575.95 \\
(0.34 \%)\end{array}$ & 20 & $\begin{array}{l}2782.86 \\
(2.73 \%)\end{array}$ & $\begin{array}{c}17.76 \\
(3.13 \%) \\
\end{array}$ & $\begin{array}{c}156.69 \\
(0.73 \%)\end{array}$ \\
\hline 12 & $\begin{array}{c}198.36 \\
(2.77 \%)\end{array}$ & $\begin{array}{c}442.47 \\
(2.87 \%)\end{array}$ & $\begin{array}{c}0.0024 \\
(0.19 \%)\end{array}$ & $\begin{array}{c}539.88 \\
(1.84 \%)\end{array}$ & & & & \\
\hline
\end{tabular}

aYield stress determined by the "Offset Method", according to ASTM 370 [29]

${ }^{\mathrm{b}} \mathrm{Strain}$ at yield point, for the $0.2 \%$ offset stress

(value) Coefficient of Variation $(\mathrm{COV})=($ Standard deviation/Average $) \times 100$ 
Table 4. Main results obtained in the experimental program at the formation of the plastic hinges

Hinge at hogging region $(\mathrm{H}) \quad$ Hinge at sagging region $(\mathrm{S})$

\begin{tabular}{|c|c|c|c|c|c|c|c|c|c|c|c|c|c|c|c|c|c|c|}
\hline \multicolumn{10}{|c|}{ nimge at nogging region (П) } & \multicolumn{9}{|c|}{ Hinge at sagging region (S) } \\
\hline Slab strip ID & $\begin{array}{c}F_{y}^{H} \\
(\mathrm{kN})\end{array}$ & $\begin{array}{c}u_{y}^{H} \\
(\mathrm{~mm})\end{array}$ & $\begin{array}{c}\varepsilon_{c}^{H} \\
(\% o)\end{array}$ & $\begin{array}{c}\mathcal{E}_{c}^{S} \\
(\% o)\end{array}$ & $\begin{array}{c}\varepsilon_{s}^{S} \\
(\% o)\end{array}$ & $\begin{array}{c}\varepsilon_{s}^{H} \\
(\% o)\end{array}$ & $\begin{array}{l}\varepsilon_{f}^{H} \\
(\% \circ)\end{array}$ & $\begin{array}{c}\mathcal{E}_{f}^{S} \\
(\% \circ)\end{array}$ & $\begin{array}{l}\Delta F_{y}^{H} \\
(\mathrm{kN})\end{array}$ & $\begin{array}{c}F_{y}^{S} \\
(\mathrm{kN})\end{array}$ & $\begin{array}{c}u_{y}^{S} \\
(\mathrm{~mm})\end{array}$ & $\begin{array}{c}\varepsilon_{c}^{H} \\
(\% o)\end{array}$ & $\begin{array}{c}\mathcal{E}_{c}^{S} \\
(\% o)\end{array}$ & $\begin{array}{c}\varepsilon_{s}^{S} \\
(\% o)\end{array}$ & $\begin{array}{c}\varepsilon_{s}^{H} \\
(\% o)\end{array}$ & $\begin{array}{c}\varepsilon_{f}^{H} \\
(\% \circ)\end{array}$ & $\begin{array}{c}\mathcal{E}_{f}^{S} \\
(\% \circ)\end{array}$ & $\begin{array}{l}\Delta F_{y}^{S} \\
(\mathrm{kN})\end{array}$ \\
\hline SL15-H & 42.67 & 15.86 & -1.38 & -1.13 & 2.04 & 2.40 & ------ & ------ & ----- & 46.99 & 19.80 & -1.71 & -1.38 & 2.45 & 2.91 & ----- & ------ & ----- \\
\hline SL15s25-H & 49.13 & 18.52 & -1.74 & -1.29 & 2.32 & 2.40 & 3.19 & ------ & 6.46 & 51.36 & 20.09 & -1.93 & -1.60 & 2.40 & 2.73 & 3.47 & ------ & 4.37 \\
\hline SL15s50-H & 54.33 & 21.77 & -1.97 & -1.48 & 2.70 & 2.41 & 4.06 & ------ & 11.66 & 54.55 & 19.67 & -1.71 & -1.31 & 2.40 & 2.21 & 3.36 & ------ & 7.56 \\
\hline SL30-H & 34.97 & 13.50 & -1.28 & -1.05 & 1.55 & 2.43 & $\begin{array}{l}---- \\
\end{array}$ & ------ & ------ & 48.48 & 24.07 & -3.38 & -1.82 & 2.70 & 4.38 & ------ & ----- & ------ \\
\hline SL30s25-H & 41.97 & 16.50 & -1.45 & -1.18 & 1.68 & 2.20 & 2.61 & ------ & 7.00 & 49.90 & 24.98 & -2.80 & -1.77 & 2.50 & 2.60 & 5.90 & ------ & 1.42 \\
\hline SL30s50-H & 42.39 & 16.26 & -1.83 & -1.31 & 2.17 & 2.40 & 4.13 & ----- & 7.42 & 52.82 & 22.50 & -2.93 & -1.83 & 2.49 & 2.78 & 6.87 & $\begin{array}{l}---- \\
-\cdots\end{array}$ & 4.34 \\
\hline SL45-H & 32.50 & 12.16 & -1.01 & -0.97 & 1.15 & m.d. & $\begin{array}{l}----- \\
\end{array}$ & ------ & $\begin{array}{l}----- \\
\end{array}$ & 50.20 & 27.88 & -4.05 & -2.11 & m.d. & m.d. & ------ & $\begin{array}{l}----- \\
\end{array}$ & ------ \\
\hline SL45s25-H & 33.59 & 12.27 & -1.08 & -0.86 & 1.11 & m.d. & 2.97 & ------ & 1.09 & 53.42 & 25.57 & -5.15 & -3.54 & 2.40 & 2.38 & 11.95 & ------ & 3.22 \\
\hline SL45s50-H & 38.00 & 14.45 & -1.22 & -1.06 & 1.62 & m.d. & 2.93 & ------ & 5.50 & 54.37 & 24.08 & -2.48 & -1.71 & 2.50 & 1.81 & 6.82 & ------ & 4.17 \\
\hline SL15-HS & 39.24 & 15.66 & -2.07 & -1.58 & 2.10 & 2.30 & $\begin{array}{ll}---- \\
-\end{array}$ & ----- & ------ & 44.24 & 20.22 & -3.68 & -2.01 & 2.30 & 3.37 & ----- & $\begin{array}{l}---- \\
\end{array}$ & ----- \\
\hline SL15s25-HS & 46.32 & 18.06 & -2.10 & -1.63 & m.d & m.d & 2.18 & 1.45 & 7.08 & 57.67 & 24.93 & -3.62 & -2.38 & m.d & m.d & 4.75 & 2.69 & 13.43 \\
\hline SL30-HS & 35.58 & 14.53 & -1.70 & -1.48 & 1.85 & 2.61 & ----- & $\begin{array}{l}---- \\
\end{array}$ & ----- & 45.70 & 23.92 & -4.80 & -2.29 & 2.65 & 2.90 & $\begin{array}{l}---- \\
\end{array}$ & $\begin{array}{l}---- \\
\end{array}$ & ------ \\
\hline SL30s25-HS & 39.94 & 14.04 & -1.63 & -1.66 & 1.81 & 2.51 & 1.92 & 1.00 & 4.36 & 56.38 & 24.26 & -4.15 & -2.69 & 2.77 & 2.25 & 7.33 & 2.93 & 10.68 \\
\hline SL30s50-HS & 42.13 & 14.92 & -1.83 & -1.51 & 1.45 & 2.66 & 1.25 & 0.88 & 6.55 & 64.20 & 27.09 & -4.20 & -2.88 & 2.68 & 2.40 & 3.65 & 3.41 & 18.50 \\
\hline SL45-HS & 31.99 & 11.35 & -1.38 & -1.10 & 1.52 & 2.37 & ---- & ---- & ------ & 50.07 & 25.00 & -5.26 & -2.25 & 2.67 & 2.76 & ----- & ----- & ------ \\
\hline SL45s25-HS & 32.02 & 11.50 & -0.88 & -0.57 & 1.85 & 2.51 & 1.94 & 0.88 & 0.03 & 56.44 & 25.76 & -4.06 & -1.95 & 2.77 & 4.06 & 9.66 & 3.12 & 6.37 \\
\hline SL45s50-HS & 33.33 & 11.18 & -0.91 & -2.10 & m.d. & 2.73 & 1.42 & 0.96 & 1.34 & (a) & (a) & (a) & (a) & (a) & (a) & (a) & (a) & (a) \\
\hline
\end{tabular}

(a) - is not presented since the reactions are not available due to a deficient functioning of the data acquisition system during the test of this slab; m.d. - SG mechanically damaged 
Table 5. Main results obtained in the experimental program at the concrete crushing initiation

Concrete crushing initiation at hogging region $\left(\varepsilon_{c u}^{H}=3.5 \%\right)$

\begin{tabular}{|c|c|c|c|c|c|c|c|c|c|c|c|c|c|c|c|c|c|c|}
\hline Slab strip ID & $\begin{array}{c}F_{c u}^{H} \\
(\mathrm{kN})\end{array}$ & $\begin{array}{c}u_{c u}^{H} \\
(\mathrm{~mm})\end{array}$ & $\begin{array}{l}\mathcal{E}_{c, \max }^{S} \\
(\% o)\end{array}$ & $\begin{array}{l}\mathcal{E}_{s, \max }^{S} \\
(\% o)\end{array}$ & $\begin{array}{l}\mathcal{E}_{s, \max }^{H} \\
(\% o)\end{array}$ & $\begin{array}{c}\mathcal{E}_{f, \max }^{H} \\
(\% o)\end{array}$ & $\begin{array}{c}\mathcal{E}_{f, \max }^{S} \\
(\% o)\end{array}$ & $\begin{array}{c}\eta \\
(\%)\end{array}$ & $\begin{array}{l}\text { IR } \\
(\%)\end{array}$ & $\begin{array}{c}F_{c u}^{S} \\
(\mathrm{kN})\end{array}$ & $\begin{array}{c}u_{c u}^{S} \\
(\mathrm{~mm})\end{array}$ & $\begin{array}{l}\mathcal{E}_{c, \max }^{H} \\
(\% \circ)\end{array}$ & $\begin{array}{l}\mathcal{E}_{s, \max }^{S} \\
(\% \circ)\end{array}$ & $\begin{array}{l}\varepsilon_{s, \max }^{H} \\
(\% o)\end{array}$ & $\begin{array}{c}\mathcal{E}_{f, \max }^{H} \\
(\% o)\end{array}$ & $\begin{array}{l}\mathcal{E}_{f, \max }^{S} \\
(\% o)\end{array}$ & $\begin{array}{c}\eta \\
(\%)\end{array}$ & $\begin{array}{l}\text { IR } \\
(\%)\end{array}$ \\
\hline SL15-H & 49.21 & 25.58 & -1.79 & 3.66 & 2.46 & ----- & ----- & 8.55 & ----- & 50.60 & 32.17 & -5.13 & 3.86 & 2.49 & ----- & ----- & 0.92 & ----- \\
\hline SL15s25-H & 53.17 & 27.37 & -2.32 & 0.62 & 2.87 & 7.82 & ----- & -9.63 & 8.05 & 54.43 & 33.97 & -4.97 & 0.70 & 2.93 & 9.81 & $\begin{array}{l}---- \\
\end{array}$ & -10.74 & 7.57 \\
\hline SL15s50-H & 58.95 & 31.92 & -3.07 & 3.12 & 2.75 & 7.64 & ----- & -21.53 & 19.79 & 60.36 & 37.80 & -4.38 & 3.85 & 2.93 & 8.87 & ----- & -25.32 & 19.29 \\
\hline SL30-H & 48.51 & 24.55 & -1.86 & 2.76 & 4.45 & $\begin{array}{l}---- \\
--\end{array}$ & $\begin{array}{l}---- \\
\end{array}$ & 29.14 & ----- & 48.89 & 31.48 & -5.14 & 0.37 & 5.89 & $\begin{array}{l}---- \\
--\end{array}$ & $\begin{array}{l}---- \\
--\end{array}$ & 26.37 & $\begin{array}{l}---- \\
-\cdots\end{array}$ \\
\hline SL30s25-H & 51.39 & 28.59 & -2.47 & 2.61 & 2.64 & 7.35 & ----- & 15.26 & 5.94 & 52.63 & 32.15 & -4.06 & 2.57 & 2.66 & 8.58 & ----- & 15.40 & 7.65 \\
\hline SL30s50-H & 52.93 & 25.05 & -2.29 & 4.23 & 2.88 & 8.13 & ----- & 6.24 & 9.11 & 54.31 & 28.94 & -4.12 & 2.25 & 2.98 & 9.27 & ----- & 5.01 & 11.09 \\
\hline SL45-H & 50.89 & 25.42 & -1.91 & 1.70 & m.d. & ----- & $\begin{array}{l}---- \\
\end{array}$ & 46.12 & $\begin{array}{l}---- \\
\end{array}$ & 51.31 & 33.03 & -4.97 & 0.90 & m.d. & $\begin{array}{l}---- \\
\end{array}$ & $\begin{array}{l}---- \\
\end{array}$ & 43.25 & $\begin{array}{l}---- \\
-\end{array}$ \\
\hline SL45s25-H & 52.35 & 24.28 & -1.73 & 1.15 & m.d. & 9.64 & $\begin{array}{ll}---- \\
-\end{array}$ & 36.59 & 2.87 & 53.38 & 33.36 & -5.13 & 2.33 & m.d. & 11.92 & ----- & 35.68 & 4.03 \\
\hline SL45s50-H & 55.21 & 31.70 & -3.03 & 1.96 & m.d. & 9.33 & ----- & 23.21 & 8.49 & 55.77 & 33.76 & -3.70 & 2.06 & m.d. & 9.80 & ----- & 22.45 & 8.69 \\
\hline SL15-HS & 43.81 & 19.70 & -1.95 & 2.43 & 3.40 & $\begin{array}{l}---- \\
\end{array}$ & ----- & (na) & $\begin{array}{l}---- \\
\end{array}$ & 45.55 & 24.69 & -6.53 & 14.63 & 9.51 & $\begin{array}{l}---- \\
-\end{array}$ & $\begin{array}{l}---- \\
-\end{array}$ & (na) & ----- \\
\hline SL15s25-HS & 56.72 & 24.04 & -2.25 & m.d. & m.d. & 4.47 & 2.38 & 6.76 & 29.47 & 62.00 & 30.35 & -4.59 & m.d. & m.d. & 6.10 & 5.07 & 6.20 & 36.11 \\
\hline SL30-HS & 41.28 & 19.74 & -1.88 & 2.37 & 2.84 & ----- & ----- & 14.00 & ----- & 46.14 & 30.51 & -6.25 & 2.84 & 2.87 & $\overline{-----}$ & ----- & 19.94 & $\overline{-----}$ \\
\hline SL30s25-HS & 53.06 & 21.88 & -2.38 & 2.75 & 2.42 & 6.52 & 2.52 & 18.21 & 28.54 & 59.91 & 28.54 & -5.09 & 4.42 & 2.51 & 8.46 & 5.59 & 21.45 & 29.84 \\
\hline SL30s50-HS & 57.77 & 22.85 & -2.35 & 2.40 & 2.24 & 2.39 & 2.58 & 24.98 & 39.95 & 68.95 & 30.94 & -4.98 & 0.82 & 2.06 & 4.69 & 4.61 & 29.89 & 49.44 \\
\hline SL45-HS & 43.52 & 19.42 & -1.82 & 2.35 & 2.66 & $\begin{array}{l}---- \\
\end{array}$ & $\begin{array}{l}---- \\
\end{array}$ & 34.17 & $\begin{array}{l}---- \\
\end{array}$ & 50.24 & 29.87 & -5.61 & 2.29 & 2.85 & ----- & $\begin{array}{l}---- \\
\end{array}$ & 39.21 & ----- \\
\hline SL45s25-HS & 52.48 & 23.06 & -1.48 & 3.77 & 6.52 & 8.74 & 2.04 & 38.18 & 20.59 & 62.51 & 34.56 & -6.04 & 1.47 & 5.20 & 11.78 & 6.83 & 41.69 & 24.42 \\
\hline SL45s50-HS & 65.18 & 25.92 & -3.23 & m.d. & 6.65 & 8.64 & 2.97 & 42.89 & 49.77 & 68.95 & 28.33 & -3.95 & m.d. & 6.10 & 9.25 & 4.03 & 44.10 & 37.24 \\
\hline
\end{tabular}

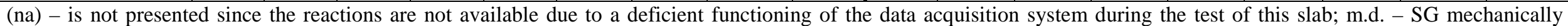
damaged 
Table 6. Main results obtained in the experimental program at the average maximum load.

\begin{tabular}{|c|c|c|c|c|c|c|c|c|c|c|}
\hline Slab strip ID & $\begin{array}{l}F_{\max } \\
(\mathrm{kN})\end{array}$ & $\begin{array}{l}u_{F_{\max }} \\
(\mathrm{mm})\end{array}$ & $\begin{array}{c}\mathcal{E}_{c, \text { max }, F_{\max }}^{S} \\
(\% o)\end{array}$ & $\begin{array}{c}\mathcal{E}_{c, \text { max }, F_{\max }}^{H}(\% o) \\
(\%)\end{array}$ & $\begin{array}{c}\mathcal{E}_{s, \max , F_{\max }}^{S} \\
(\% o)\end{array}$ & $\begin{array}{c}\mathcal{E}_{s, \text { max }, F_{\max }}^{H} \\
(\% o)\end{array}$ & $\begin{array}{c}\mathcal{E}_{f, \max , F_{\max }}^{H}(\%) \\
(\%)\end{array}$ & $\begin{array}{c}\mathcal{E}_{f, \max , F_{\max }}^{S} \\
(\% o)\end{array}$ & $\begin{array}{c}\eta \\
(\%)\end{array}$ & $\begin{array}{l}\text { IR } \\
(\%)\end{array}$ \\
\hline SL15-H & 51.36 & 55.04 & -6.44 & m.d. & 1.39 & 2.41 & ----- & ----- & 7.85 & ----- \\
\hline SL15s25-H & 57.60 & 81.01 & -3.55 & -10.86 & 0.93 & 2.41 & 16.61 & ----- & -20.40 & 12.15 \\
\hline SL15s50-H & 62.36 & 46.25 & -5.27 & -5.12 & 0.88 & 2.21 & 10.27 & ----- & -27.64 & 21.42 \\
\hline SL30-H & 49.84 & 38.63 & -5.59 & -7.05 & 0.46 & 2.95 & ----- & ----- & 27.71 & ----- \\
\hline SL30s25-H & 54.87 & 70.27 & -9.04 & -12.53 & 1.30 & 3.62 & 15.19 & $\begin{array}{l}---- \\
\end{array}$ & 6.36 & 10.09 \\
\hline SL30s50-H & 58.09 & 57.62 & -8.35 & -7.70 & 2.39 & 2.35 & 13.30 & ----- & -2.42 & 16.55 \\
\hline SL45-H & 52.55 & 41.29 & -5.44 & -6.69 & 0.96 & m.d. & ----- & ----- & 43.62 & ----- \\
\hline SL45s25-H & 54.49 & 71.12 & m.d. & -4.34 & 0.27 & m.d. & 13.31 & ----- & 32.58 & 3.69 \\
\hline SL45s50-H & 57.79 & 51.55 & -6.43 & -5.60 & 1.25 & m.d. & 12.59 & $\begin{array}{l}---- \\
\end{array}$ & 16.73 & 9.97 \\
\hline SL15-HS & 47.61 & 54.45 & -11.26 & -14.43 & 11.54 & 9.64 & ----- & $\begin{array}{l}---- \\
\end{array}$ & (na) & ----- \\
\hline SL15s25-HS & 69.24 & 47.73 & -5.34 & -7.07 & m.d. & m.d. & 7.64 & 8.24 & 8.85 & 45.43 \\
\hline SL30-HS & 47.85 & 53.00 & -7.06 & -7.46 & 4.53 & 4.19 & ----- & ----- & 19.69 & ----- \\
\hline SL30s25-HS & 72.96 & 65.18 & -8.85 & -10.83 & 4.26 & 4.62 & 12.75 & 11.48 & 26.58 & 52.48 \\
\hline SL30s50-HS & 80.42 & 49.19 & -5.47 & -6.91 & 0.57 & 2.22 & 9.85 & 7.60 & 31.67 & 68.07 \\
\hline SL45-HS & 53.27 & 51.52 & -8.05 & -9.89 & 1.79 & 2.69 & ---- & ----- & 38.93 & ----- \\
\hline SL45s25-HS & 68.48 & 52.33 & -5.26 & -10.08 & 1.51 & 11.07 & 14.73 & 10.44 & 37.66 & 28.55 \\
\hline SL45s50-HS & 81.57 & 43.64 & -6.58 & -5.33 & m.d. & 9.68 & 11.62 & 7.49 & 47.04 & 53.13 \\
\hline
\end{tabular}

(na) - is not presented since the reactions are not available due to a deficient functioning of the data acquisition system during the test of this slab; m.d. - SG mechanically damaged 
Table 7. Relevant experimental results at three levels of loading: $F_{y}^{H}, F_{y}^{S}$ and $F_{\max }$.

\begin{tabular}{|c|c|c|c|c|c|c|c|c|c|c|c|}
\hline \multicolumn{2}{|c|}{$\begin{array}{l}\text { Slab strip } \\
\text { ID }\end{array}$} & \multirow{2}{*}{$\begin{array}{c}F_{123} \\
(\mathrm{kN}) \\
42.94 \\
\end{array}$} & \multirow{2}{*}{$\begin{array}{c}\begin{array}{c}\text { MIC_200 } \\
(\mathrm{kN})\end{array} \\
13.3\end{array}$} & \multirow{2}{*}{$\begin{array}{c}\begin{array}{c}M^{+} \\
\text {(kN.m) }\end{array} \\
18.62 \\
\end{array}$} & \multirow{2}{*}{$\begin{array}{c}M^{-} \\
(\mathrm{kN} . \mathrm{m})\end{array}$} & \multicolumn{2}{|c|}{$\begin{array}{l}\text { Slab strip } \\
\text { ID }\end{array}$} & \multirow{2}{*}{$\begin{array}{c}F_{123} \\
(\mathrm{kN}) \\
46.64\end{array}$} & \multirow{2}{*}{$\begin{array}{c}\begin{array}{c}\text { MIC_200 } \\
(\mathrm{kN})\end{array} \\
14.73\end{array}$} & \multirow{2}{*}{$\frac{\begin{array}{c}M^{+} \\
(\mathrm{kN} . \mathrm{m})\end{array}}{20.62}$} & \multirow{2}{*}{$\begin{array}{c}\begin{array}{c}M^{-} \\
(\mathrm{kN} . \mathrm{m})\end{array} \\
24.05\end{array}$} \\
\hline$I$ & $F_{y}^{H}$ & & & & & \multirow{3}{*}{ 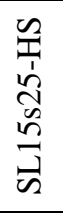 } & $F_{y}^{H}$ & & & & \\
\hline$\stackrel{n}{3}$ & $F_{y}^{S}$ & 47.18 & 15.43 & 21.60 & 22.85 & & $F_{y}^{S}$ & 58.02 & 18.84 & 26.38 & 28.48 \\
\hline & $F_{\max }$ & 51.74 & 16.93 & 23.70 & 25.03 & & $F_{\max }$ & 69.34 & 22.82 & 31.95 & 33.18 \\
\hline \multirow{3}{*}{$\begin{array}{l}\frac{\pi}{n} \\
\stackrel{n}{n} \\
n \\
\frac{n}{n}\end{array}$} & $F_{y}^{H}$ & 49.06 & 14.66 & 20.52 & 27.64 & \multirow{3}{*}{ 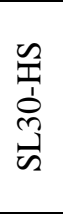 } & $F_{y}^{H}$ & 35.1 & 11.19 & 15.67 & 17.81 \\
\hline & $F_{y}^{S}$ & 51.47 & 15.56 & 21.788 & 28.49 & & $F_{y}^{S}$ & 44.95 & 15.75 & 22.05 & 18.83 \\
\hline & $F_{\max }$ & 57.43 & 15.75 & 22.05 & 36.302 & & $F_{\max }$ & 47.02 & 16.43 & 23.00 & 19.82 \\
\hline \multirow{3}{*}{ 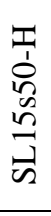 } & $F_{y}^{H}$ & 53.67 & 15.05 & 21.07 & 32.99 & \multirow{3}{*}{ 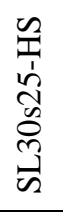 } & $F_{y}^{H}$ & 39.23 & 12.90 & 18.06 & 18.80 \\
\hline & $F_{y}^{S}$ & 54.72 & 15.87 & 22.22 & 32.17 & & $F_{y}^{S}$ & 55.55 & 19.49 & 27.29 & 23.120 \\
\hline & $F_{\max }$ & 62.11 & 16.19 & 22.67 & 41.62 & & $F_{\max }$ & 72.28 & 26.19 & 36.67 & 27.86 \\
\hline \multirow{3}{*}{\begin{tabular}{l}
$\frac{\pi}{1}$ \\
$\stackrel{n}{n}$ \\
\multirow{n}{n}{}
\end{tabular}} & $F_{y}^{H}$ & 35.15 & 11.74 & 16.44 & 16.34 & \multirow{3}{*}{ 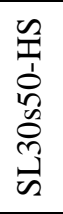 } & $F_{y}^{H}$ & 41.16 & 14.21 & 19.89 & 17.84 \\
\hline & $F_{y}^{S}$ & 49.17 & 18.03 & 25.24 & 18.35 & & $F_{y}^{S}$ & 62.67 & 22.97 & 32.16 & 23.42 \\
\hline & $F_{\max }$ & 49.69 & 18.11 & 25.35 & 18.86 & & $F_{\max }$ & 79.59 & 29.89 & 41.85 & 27.73 \\
\hline \multirow{3}{*}{ 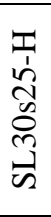 } & $F_{y}^{H}$ & 41.53 & 13.87 & 19.42 & 19.31 & \multirow{3}{*}{ 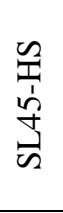 } & $F_{y}^{H}$ & 31.79 & 11.19 & 15.67 & 13.17 \\
\hline & $F_{y}^{S}$ & 49.56 & 16.96 & 23.74 & 21.90 & & $F_{y}^{S}$ & 49.46 & 19.03 & 26.64 & 15.96 \\
\hline & $F_{\max }$ & 53.54 & 17.37 & 24.32 & 26.32 & & $F_{\max }$ & 52.45 & 20.22 & 28.31 & 16.81 \\
\hline \multirow{3}{*}{ 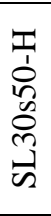 } & $F_{y}^{H}$ & 41.83 & 13.4 & 18.76 & 21.04 & \multirow{3}{*}{ 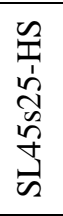 } & $F_{y}^{H}$ & 29.92 & 10.76 & 15.06 & 11.76 \\
\hline & $F_{y}^{S}$ & 52.56 & 17.34 & 24.28 & 25.03 & & $F_{y}^{S}$ & 53.82 & 20.85 & 29.19 & 16.97 \\
\hline & $F_{\max }$ & 58.09 & 17.89 & 25.05 & 31.23 & & $F_{\max }$ & 67.22 & 26.22 & 36.71 & 20.69 \\
\hline \multirow{3}{*}{$\begin{array}{l}\frac{\pi}{1} \\
\stackrel{1}{+} \\
\stackrel{5}{\sim}\end{array}$} & $F_{y}^{H}$ & 32.08 & 11.67 & 16.34 & 12.24 & \multirow{3}{*}{ 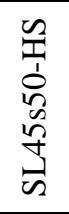 } & $F_{y}^{H}$ & 32.48 & 11.81 & 16.53 & 12.40 \\
\hline & $F_{y}^{S}$ & 49.38 & 19.47 & 27.26 & 14.62 & & $F_{y}^{S}$ & (a) & (a) & (a) & (a) \\
\hline & $F_{\max }$ & 52.22 & 20.59 & 28.83 & 15.46 & & $F_{\max }$ & 79.96 & 32.04 & 44.86 & 22.23 \\
\hline \multirow{3}{*}{ 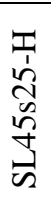 } & $F_{y}^{H}$ & 33.17 & 11.66 & 16.32 & 13.79 & \multirow{6}{*}{\multicolumn{6}{|c|}{$\begin{array}{l}\text { (a) - is not presented since the reactions are not available } \\
\text { due to a deficient functioning of the data acquisition } \\
\text { system during the test of this slab }\end{array}$}} \\
\hline & $F_{y}^{S}$ & 51.60 & 19.64 & 27.50 & 17.25 & & & & & & \\
\hline & $F_{\max }$ & 54.82 & 20.48 & 28.67 & 19.40 & & & & & & \\
\hline \multirow{3}{*}{ 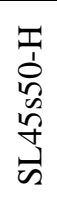 } & $F_{y}^{H}$ & 38.4 & 13.26 & 18.56 & 16.63 & & & & & & \\
\hline & $F_{y}^{S}$ & 54.91 & 20.03 & 28.04 & 20.79 & & & & & & \\
\hline & $F_{\max }$ & 57.87 & 19.9 & 27.86 & 25.30 & & & & & & \\
\hline
\end{tabular}




\section{FIGURE CAPTIONS}

Fig. 1. Slab strips: (a) test configuration and (b) displacement transducers (LVDTs). Dimensions in mm

Fig. 2. Slab strips: specimen's cross-sectional dimensions of sagging $\left(\mathrm{S}_{1}-\mathrm{S}_{1}{ }^{\prime}\right)$ and hogging regions $\left(\mathrm{S}_{2}-\mathrm{S}_{2}{ }^{\prime}\right)$. Dimensions in $\mathrm{mm}$

Fig. 3. Arrangement of strain gages in: (a) steel bars at hogging region and (b) steel bars at sagging region; (c) concrete slab surfaces, (d) CFRP laminates for SL15s25-H, (e) SL15s50-H and (f) SL15s25-HS. Dimensions in mm

Fig. 4. Arrangement of strain gages in: (a) steel bars at hogging region and (b) steel bars at sagging region;

(c) concrete slab surfaces; CFRP laminates for (d) SL30s25-H, (e) SL30s50-H, (f) SL30s25-HS and (g) SL30s50-HS. Dimensions in $\mathrm{mm}$

Fig. 5. Arrangement of strain gages in: (a) steel bars at hogging region and (b) steel bars at sagging region; (c) concrete slab surfaces; CFRP laminates for (d) SL45s25-H, (e) SL45s50-H, (f) SL45s25-HS and (g) SL45s50-HS. Dimensions in mm

Fig. 6. Apparatus to sustain and to control the mid-span deflection applied in the slab strips to be strengthened

Fig. 7. Average load-midspan deflection of the tested slab strips series: (a) SL15, (b) SL30 and (c) SL45

Fig. 8. Crack patterns of $\mathrm{H}$ series: top view of hogging region

Fig. 9. Crack patterns of HS series: view of sagging and hogging regions

Fig. 10. Crack patterns of HS series: side view of hogging region

Fig. 11. Side view of the left span of SL30s50-HS

Fig. 12. Degree of moment redistribution, $\eta$, for the slab strips series strengthened only in the hogging $(\mathrm{H})$ and in both hogging and sagging regions (HS): (a) SL15, (b) SL30, (c) SL45 Series

Fig. 13. Relationship between applied load and moment in the sagging and hogging regions for the series of slabs of the $\mathrm{H}$ group: (a) SL15, (b) SL30, (c) SL45.

Fig. 14. Relationship between applied load and moment in the sagging and hogging regions for the series of slabs of the HS group: (a) SL15, (b) SL30, (c) SL45. 
(a)

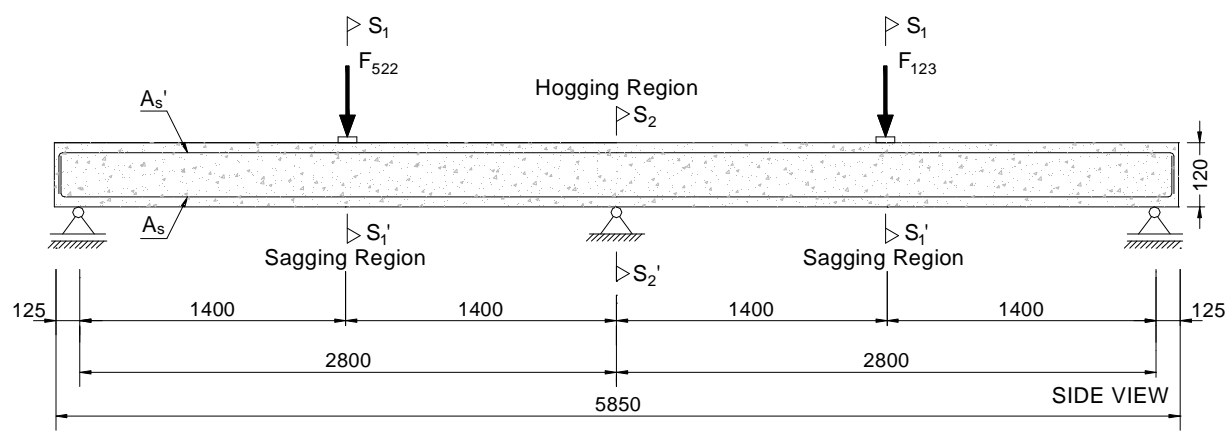

(b)

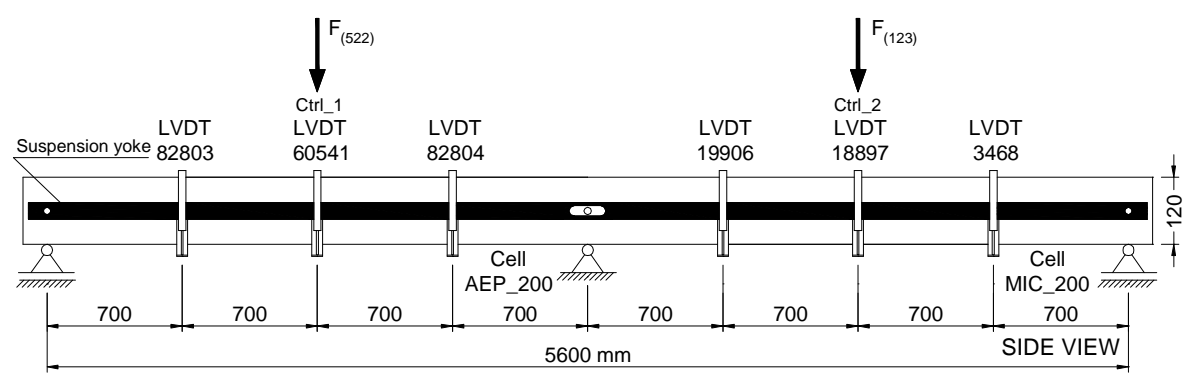

Fig. 2. Slab strips: (a) test configuration and (b) displacement transducers (LVDTs). Dimensions in mm 


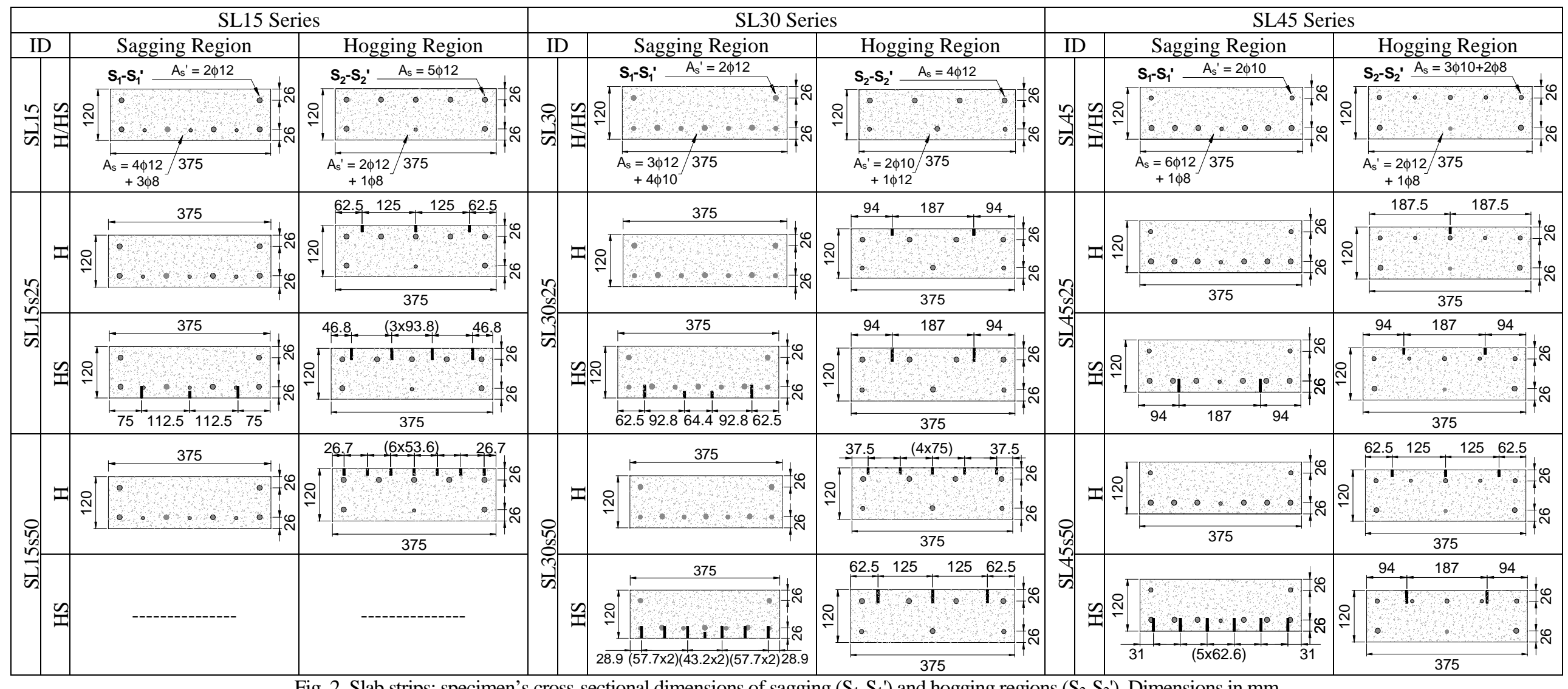

Fig. 2. Slab strips: specimen's cross-sectional dimensions of sagging $\left(\mathrm{S}_{1}-\mathrm{S}_{1}{ }^{\prime}\right)$ and hogging regions $\left(\mathrm{S}_{2}-\mathrm{S}_{2}{ }^{\prime}\right)$. Dimensions in $\mathrm{mm}$ 


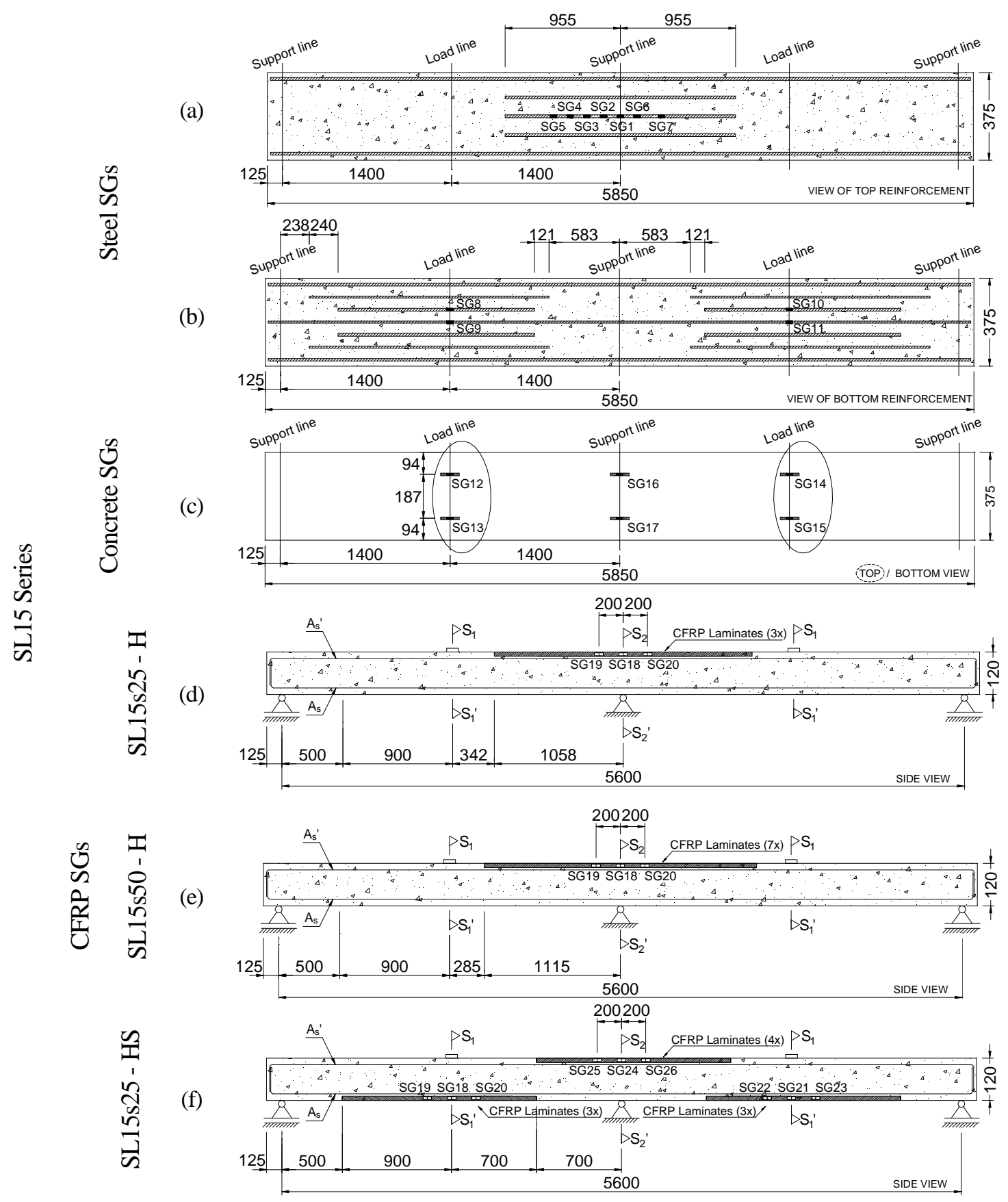

Fig. 3. Arrangement of strain gages in: (a) steel bars at hogging region and (b) steel bars at sagging region; (c) concrete slab surfaces, (d) CFRP laminates for SL15s25-H, (e) SL15s50-H and (f) SL15s25-HS. Dimensions in mm 


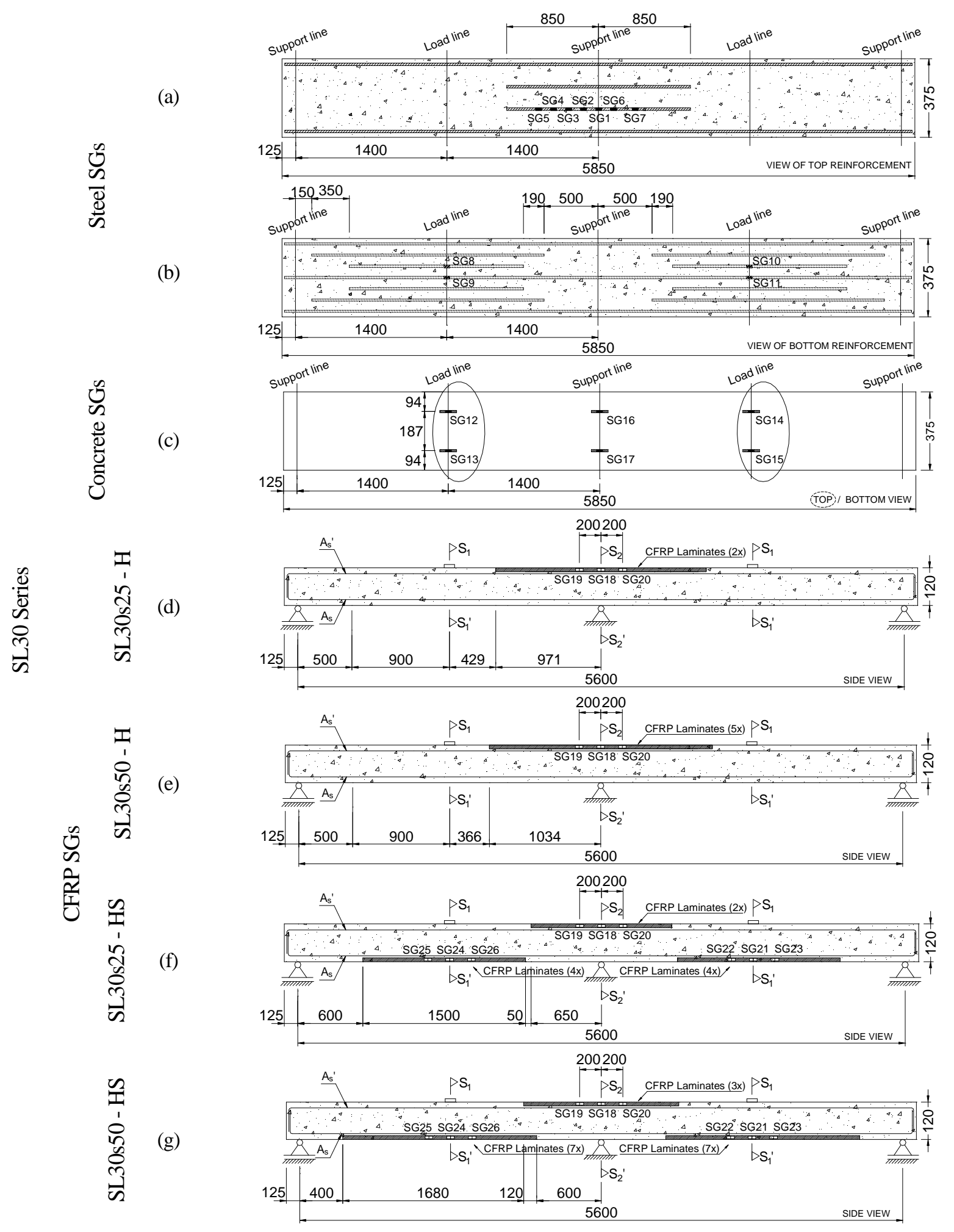

Fig. 4. Arrangement of strain gages in: (a) steel bars at hogging region and (b) steel bars at sagging region;

(c) concrete slab surfaces; CFRP laminates for (d) SL30s25-H, (e) SL30s50-H, (f) SL30s25-HS and (g) SL30s50-HS.

Dimensions in $\mathrm{mm}$ 


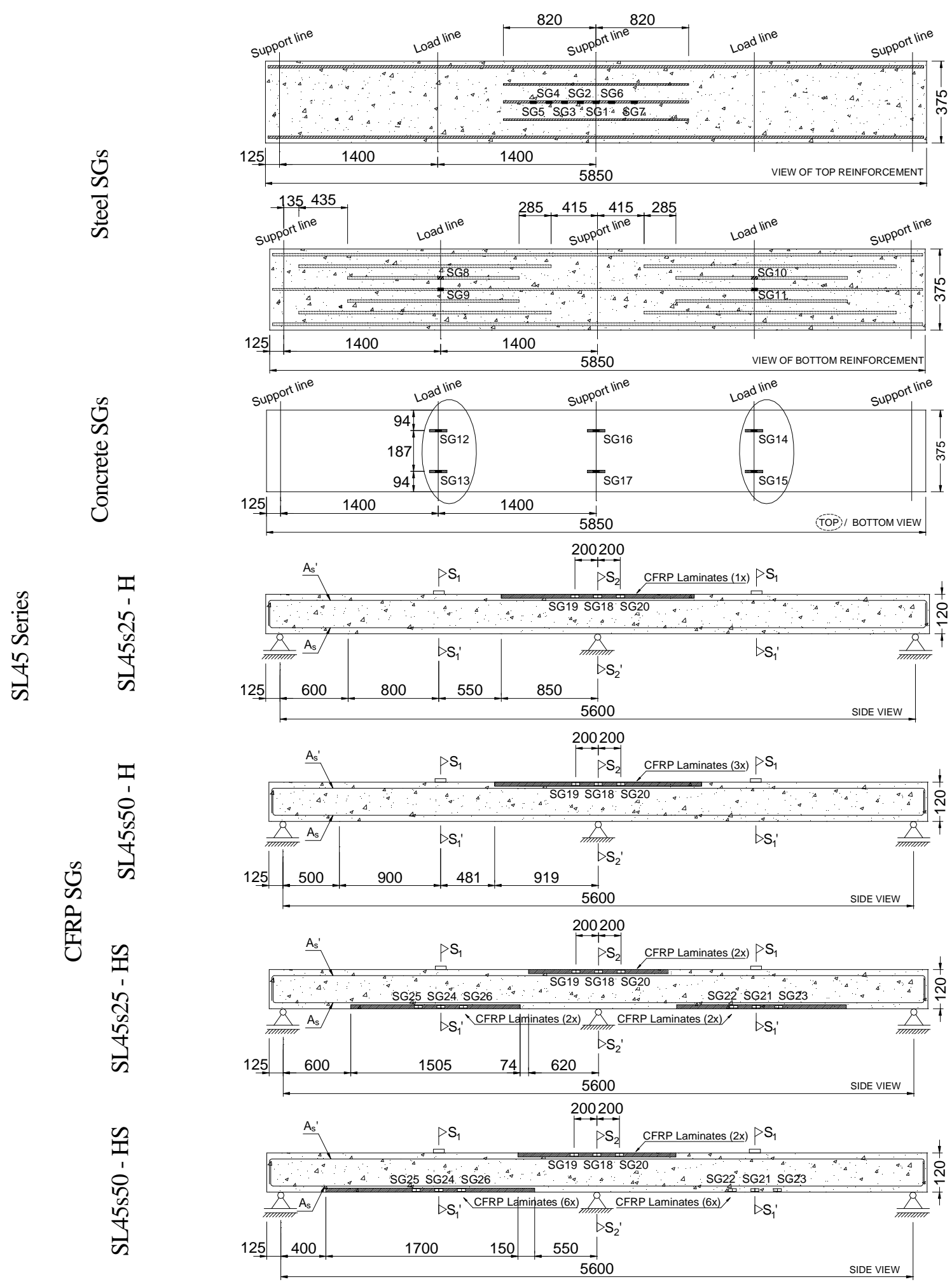

Fig. 5. Arrangement of strain gages in: (a) steel bars at hogging region and (b) steel bars at sagging region;

(c) concrete slab surfaces; CFRP laminates for (d) SL45s25-H, (e) SL45s50-H, (f) SL45s25-HS and (g) SL45s50-HS.

Dimensions in $\mathrm{mm}$ 


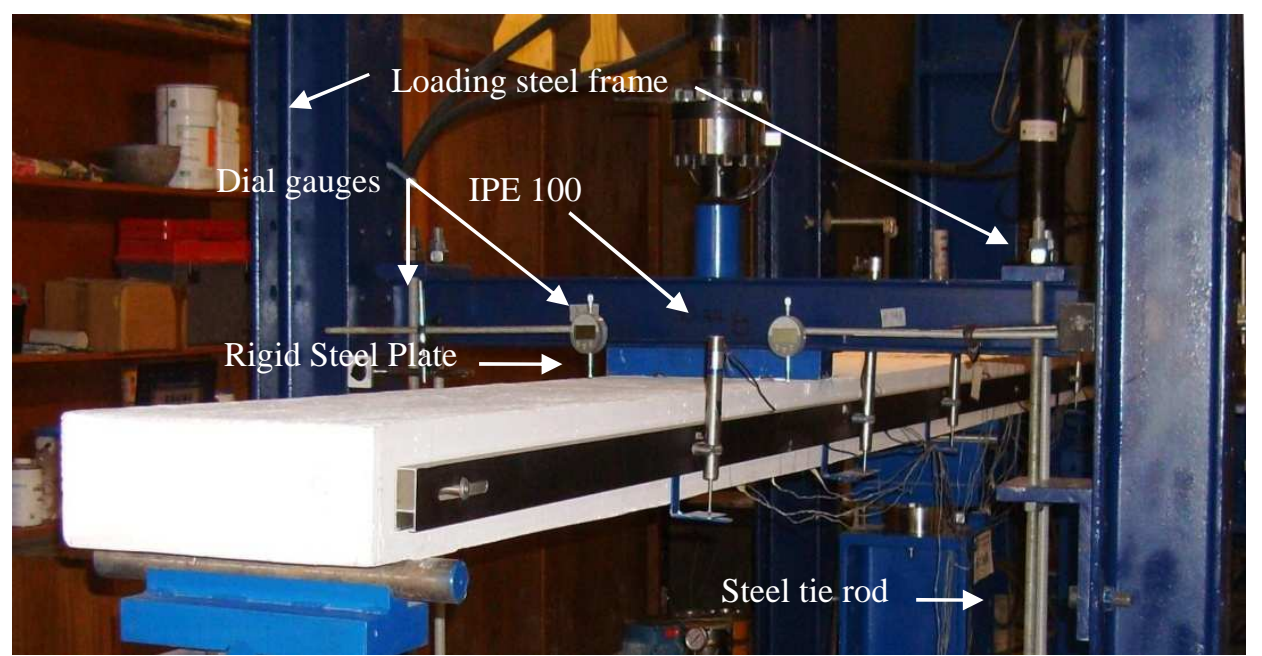

Fig. 6. Apparatus to sustain and to control the mid-span deflection applied in the slab strips to be strengthened. 

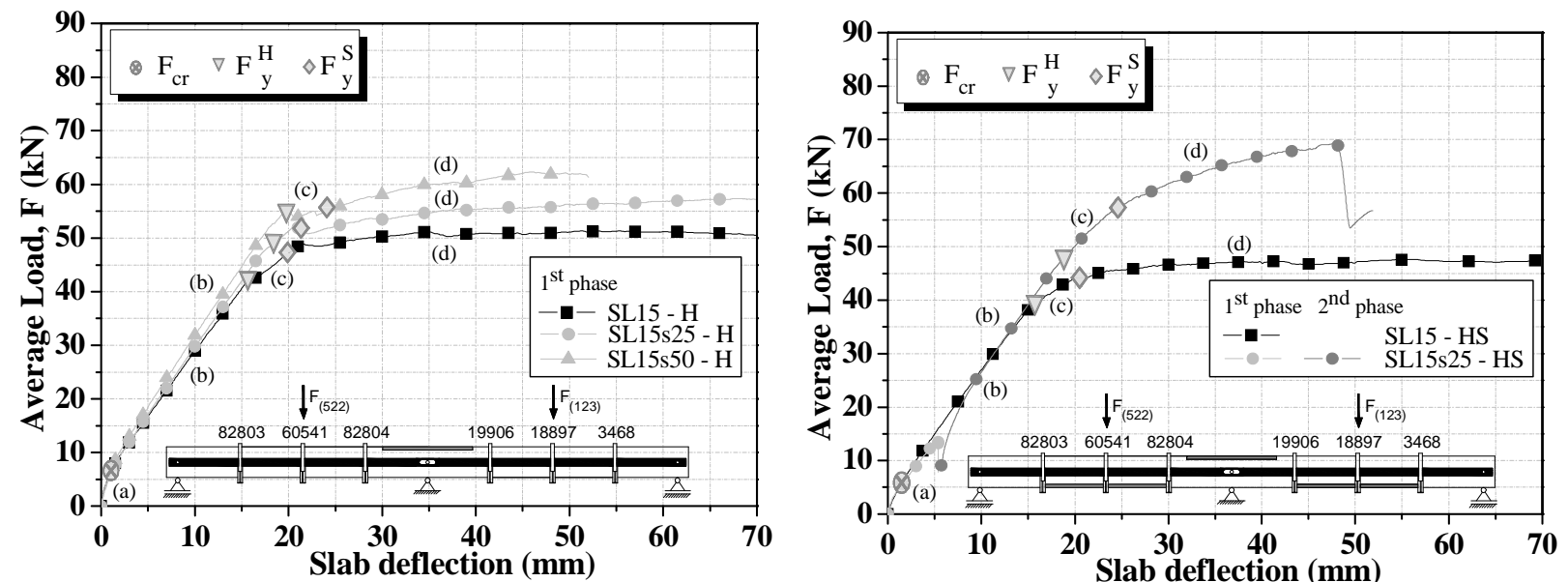

(a)
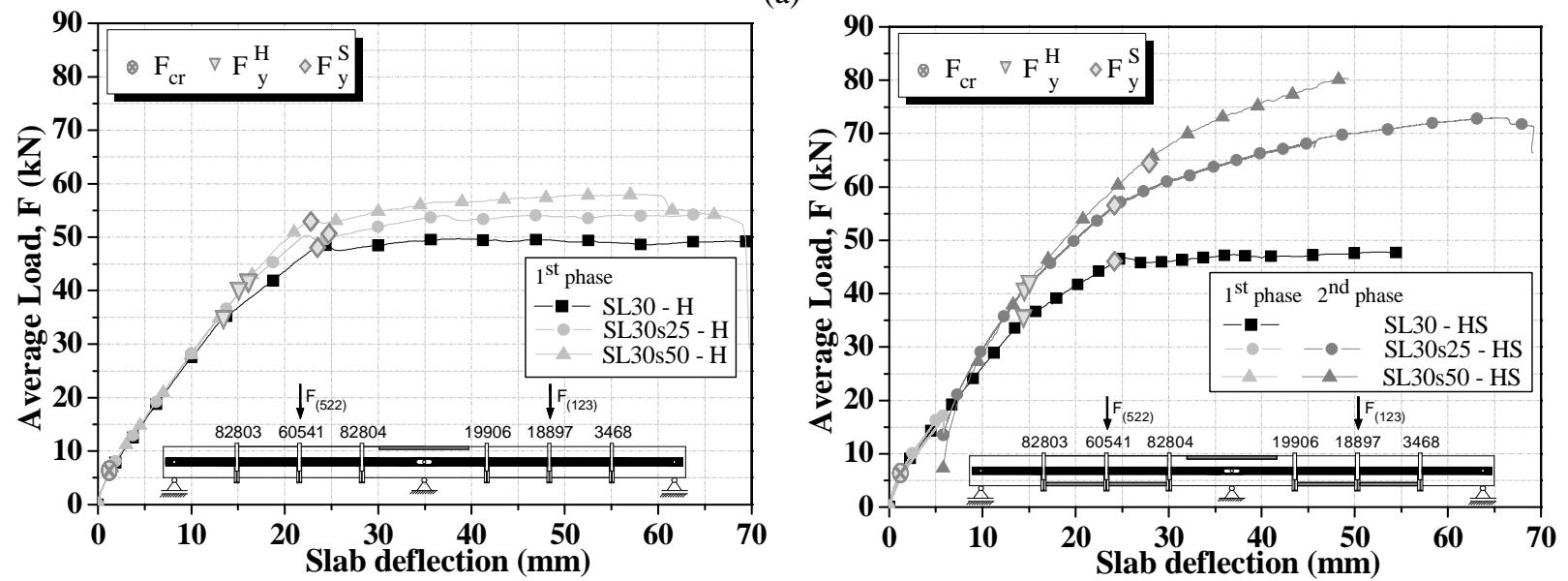

(b)
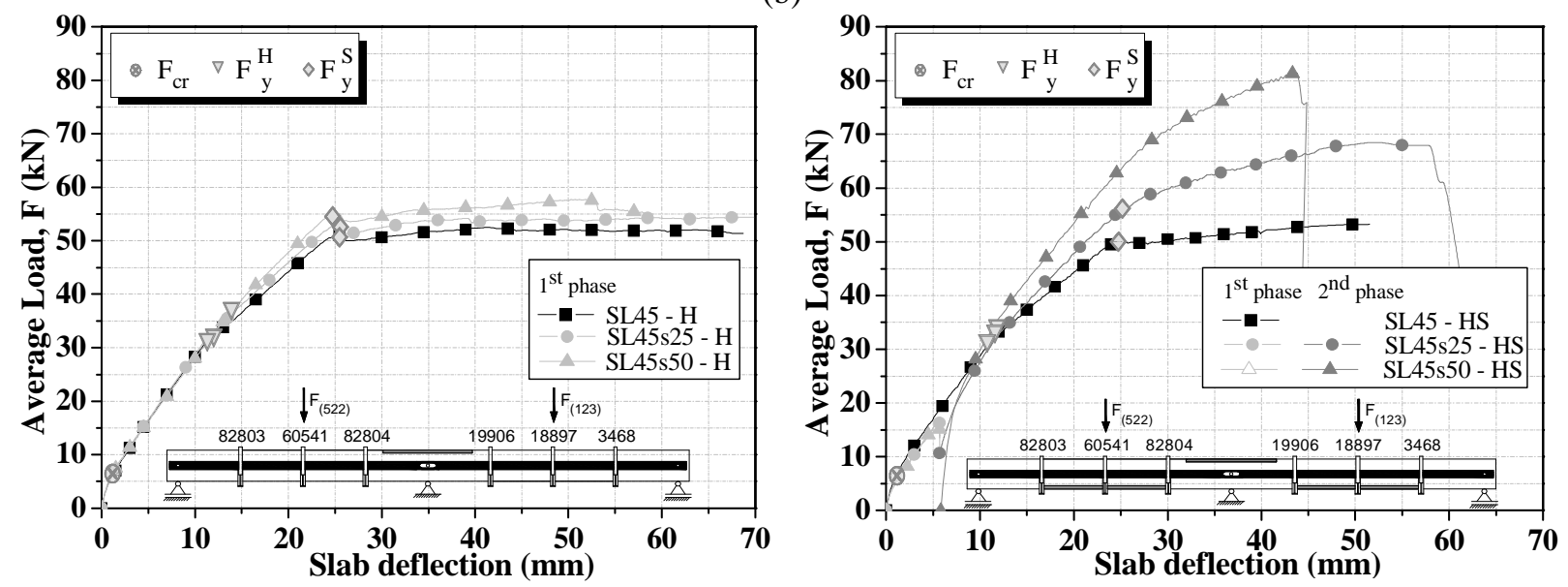

(c)

Fig. 7. Average load-midspan deflection of the tested slab strips series: (a) SL15, (b) SL30 and (c) SL45. 


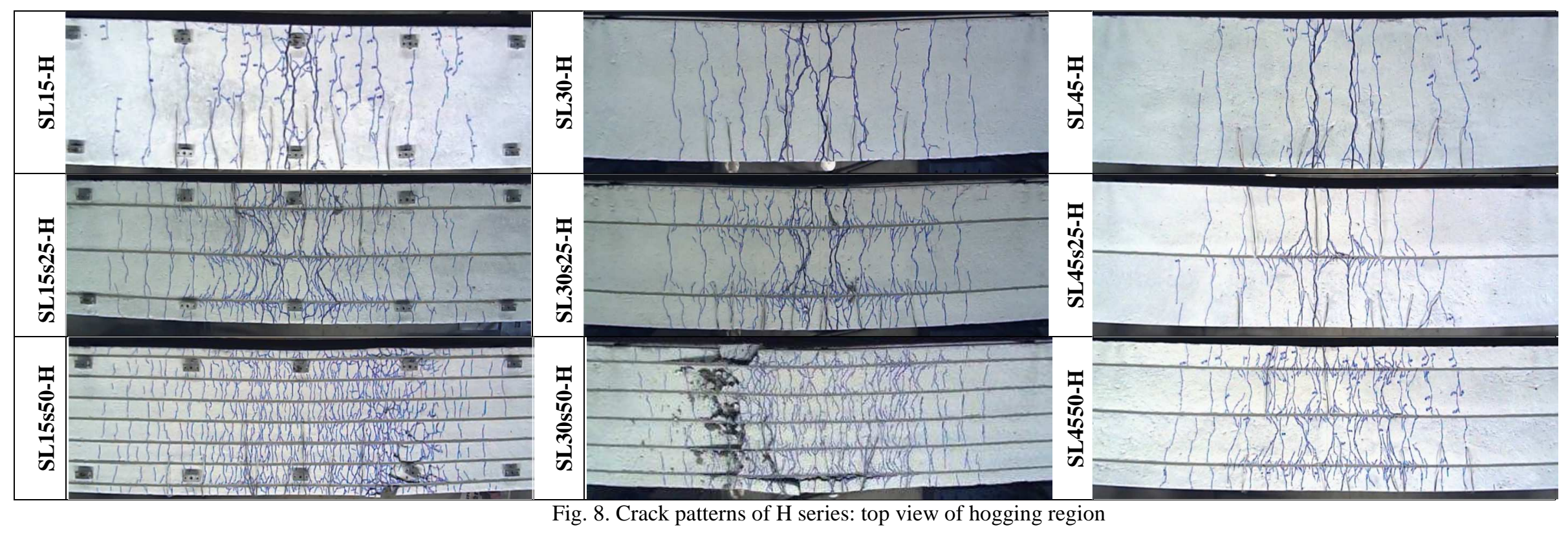



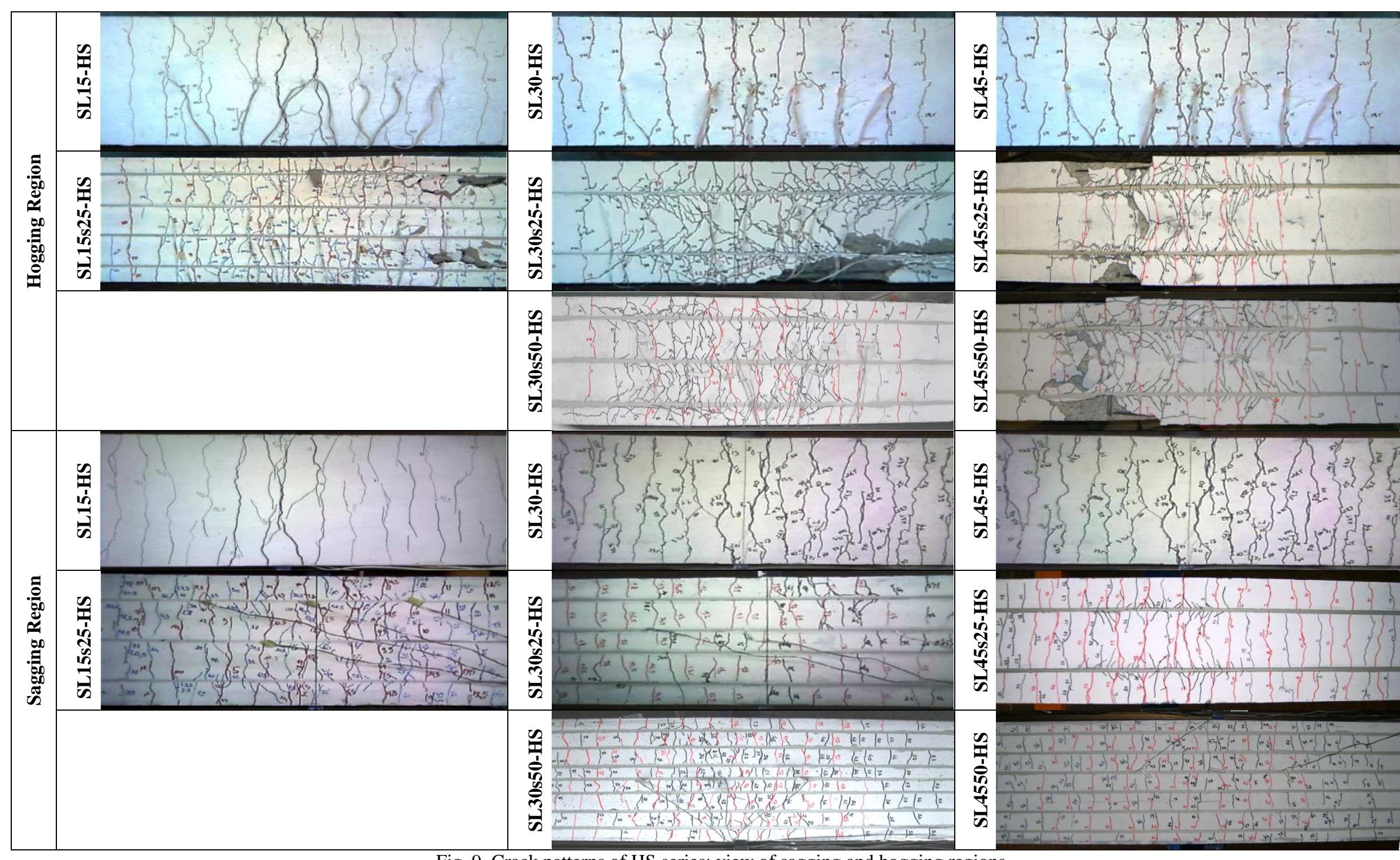

Fig. 9. Crack patterns of HS series: view of sagging and hogging regions 


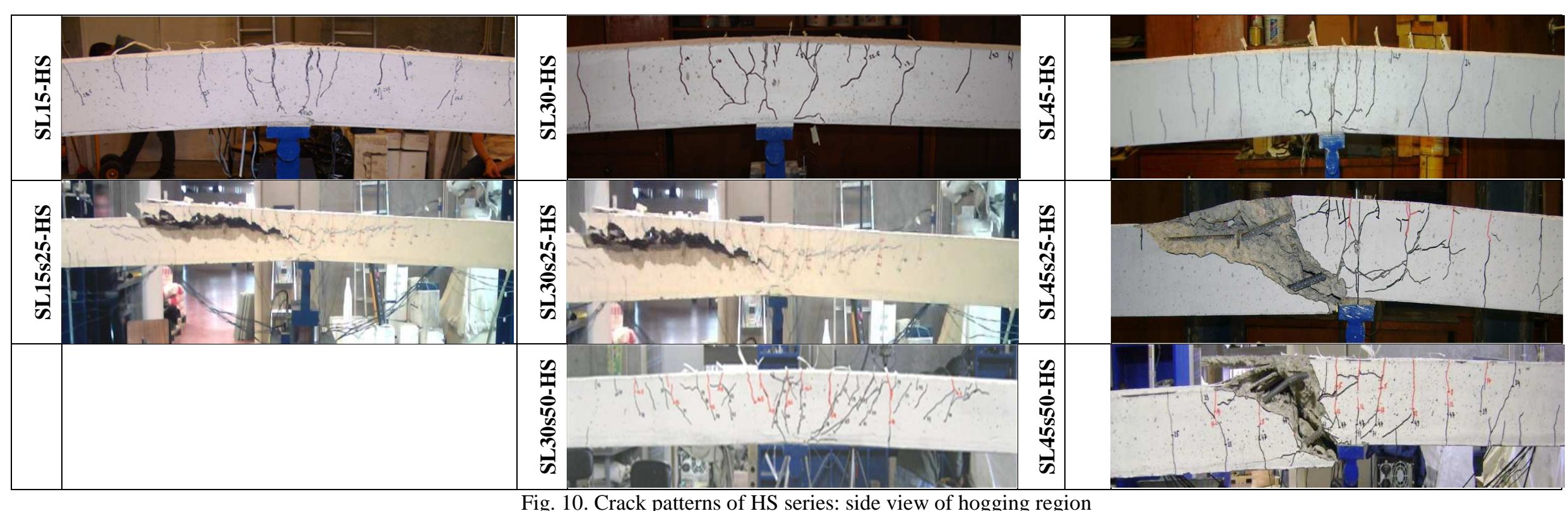



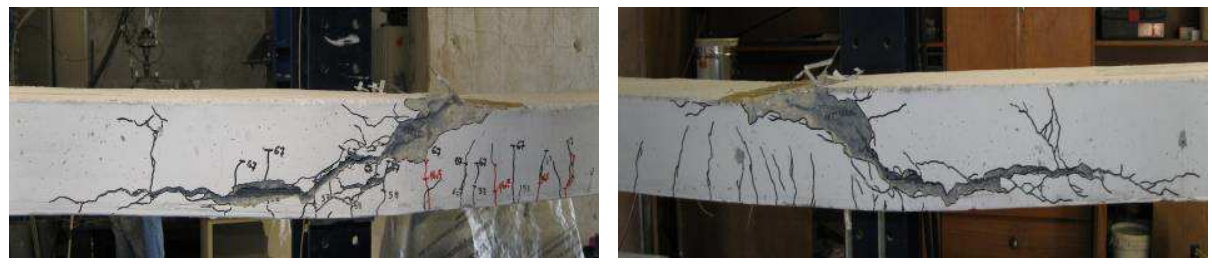

Fig. 11. Side view of the left span of SL30s50-HS 

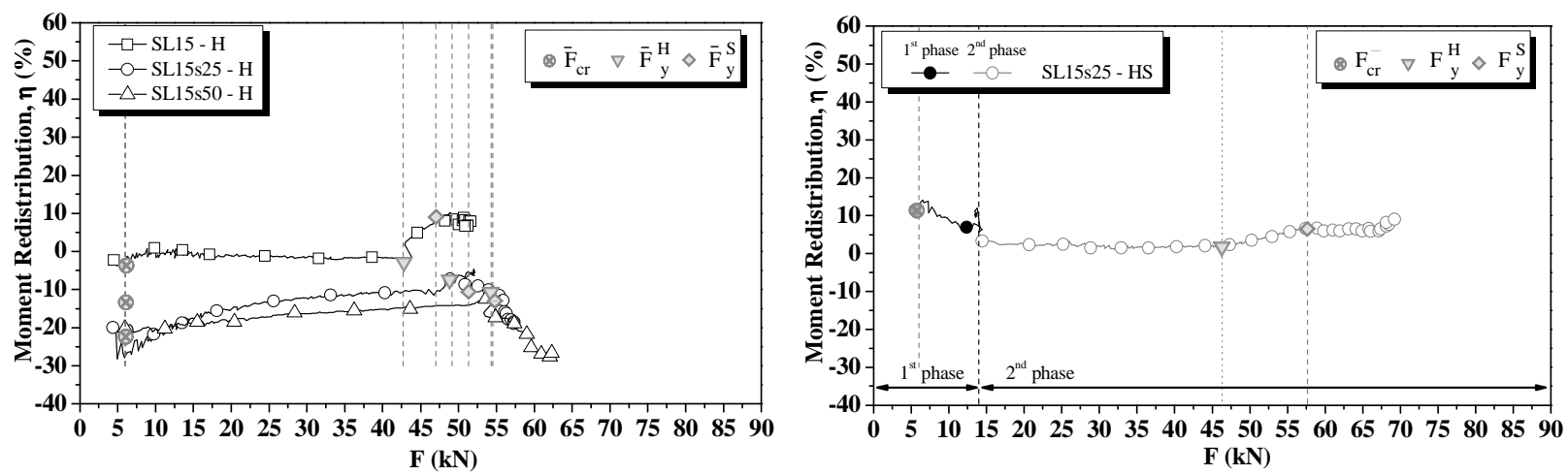

(a)
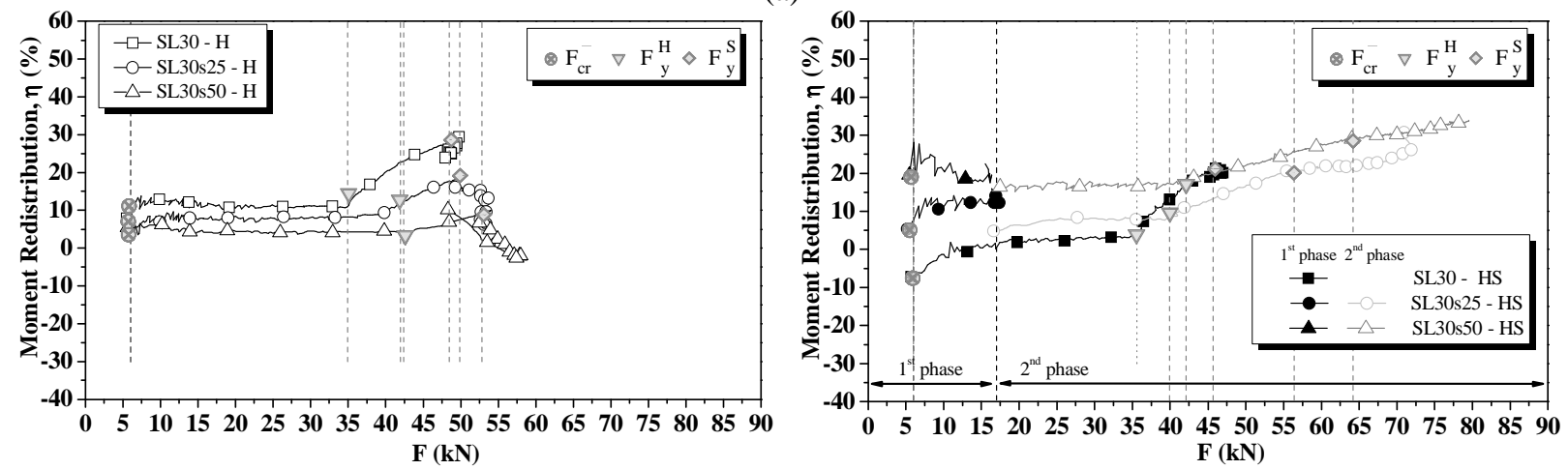

(b)
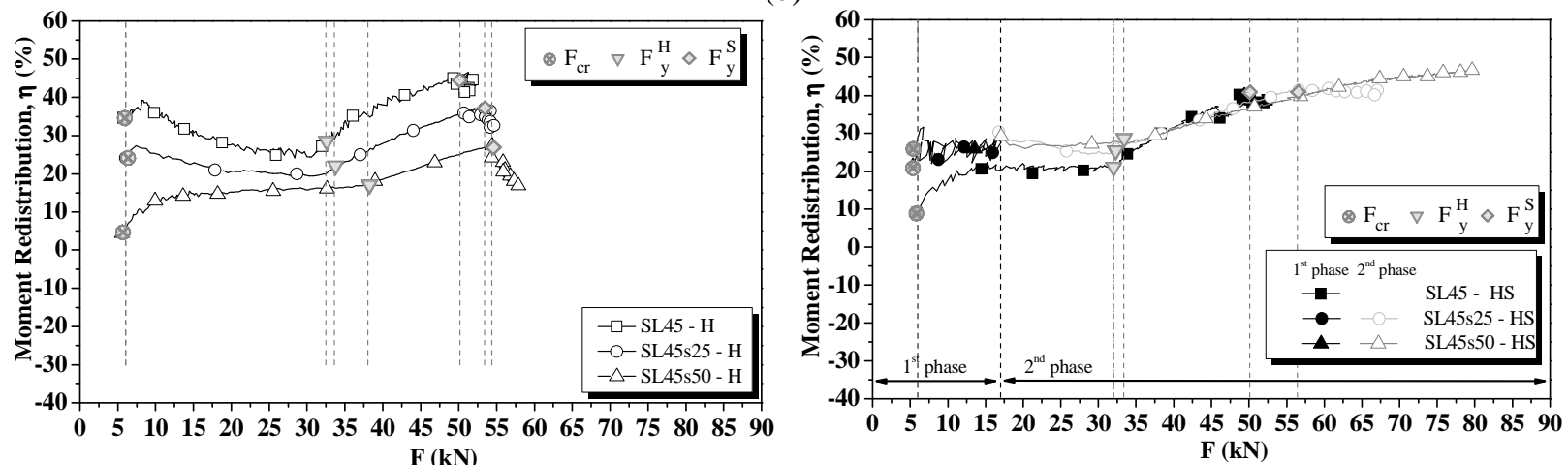

(c)

Fig. 12. Degree of moment redistribution, $\eta$, for the slab strips series strengthened only in the hogging $(\mathrm{H})$ and in both hogging and sagging regions (HS): (a) SL15, (b) SL30, (c) SL45 Series 


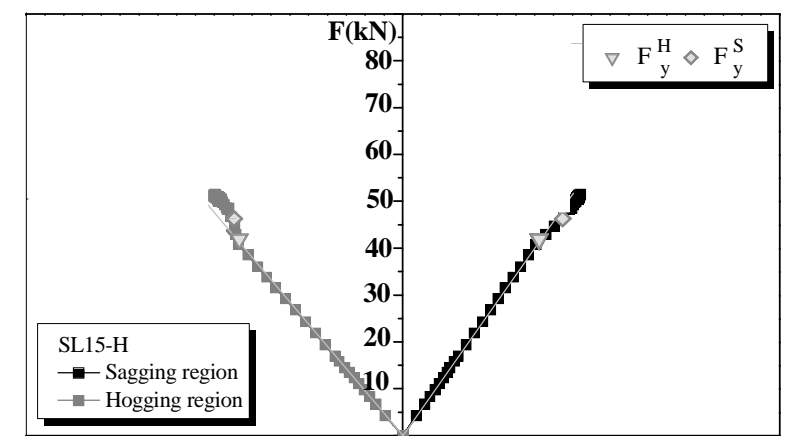

-50-45-40-35-30-25-20-15-10 -5 0 \% Moment (kN.m)

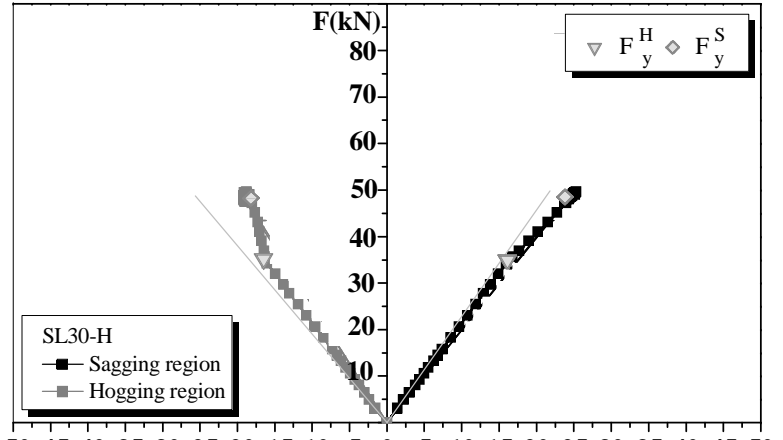

-50-45-40-35-30-25-20-15-10 -5 0 \% $5 \begin{array}{lllllllll}10 & 20 & 25 & 30 & 35 & 40 & 45 & 50\end{array}$

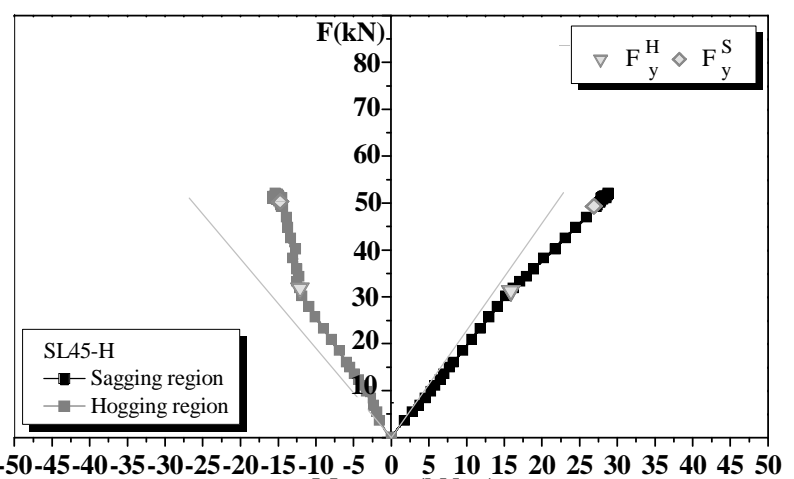

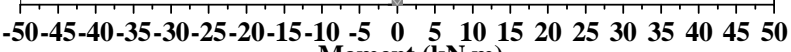

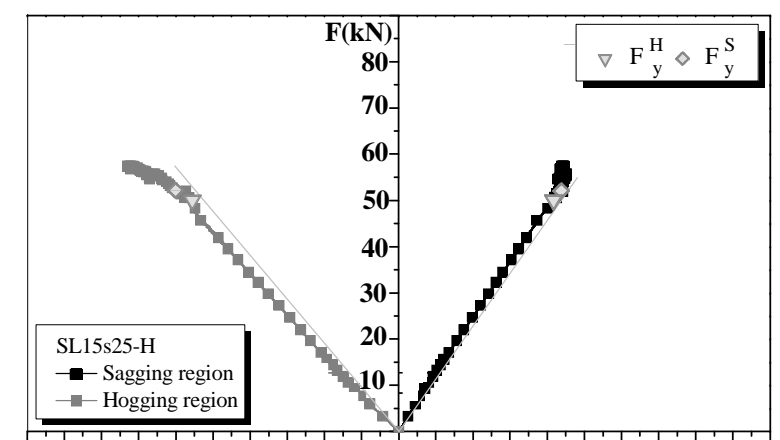

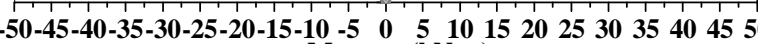
Moment (kN.m)

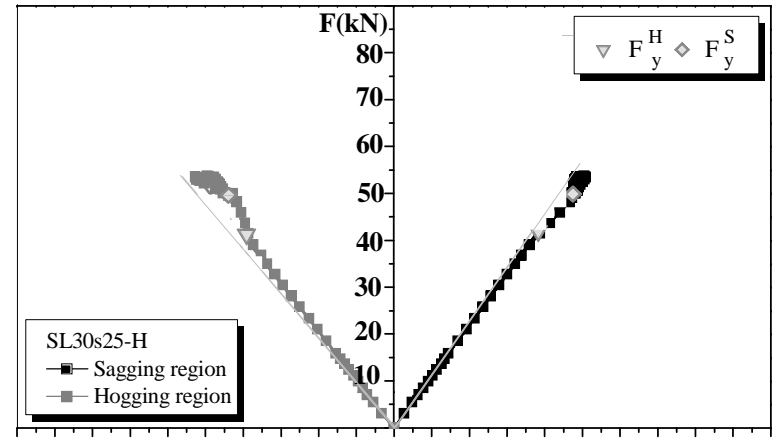

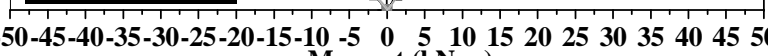
Moment (kN.m)

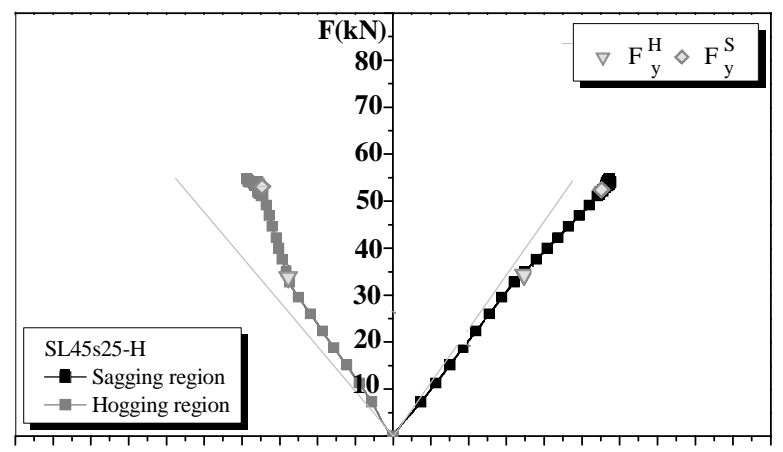

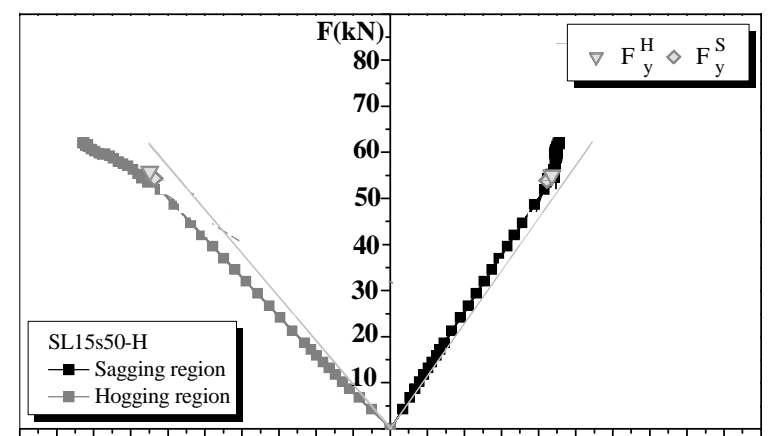

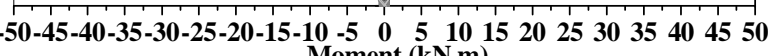

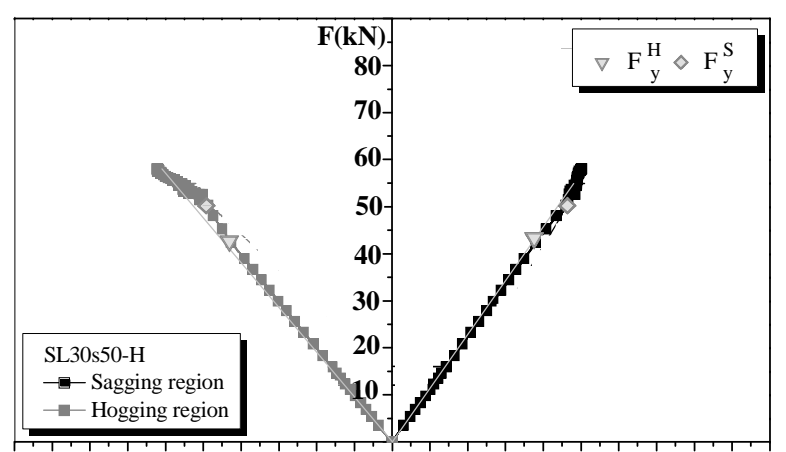

$\begin{array}{lllllllllllll}50-45-40-35-30-25-20-15-10 & -5 & 0 & 5 & 10 & 15 & 20 & 25 & 30 & 35 & 40 & 45 & 50\end{array}$

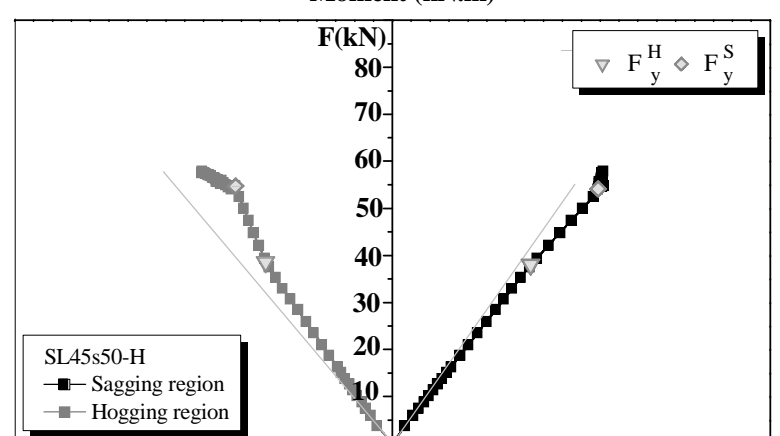
Fig. 13. Relationship between applied load and moment in the sagging and hogging regions for the series of slabs of the H group: (a) SL15, (b) SL30, (c) SL45. 


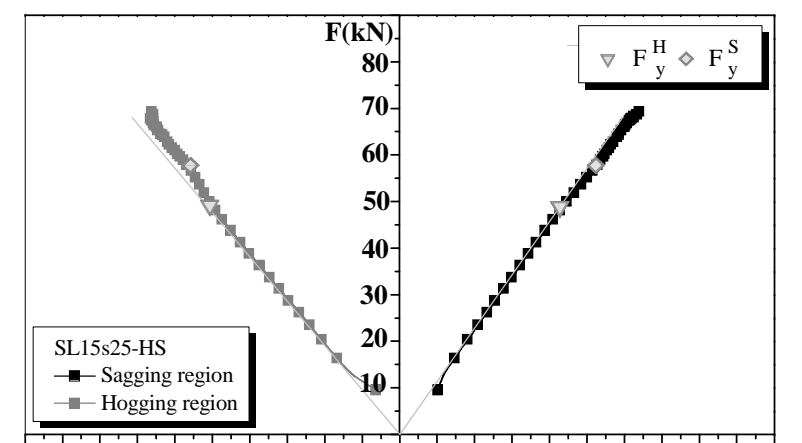

$-50-45-40-35-30-25-20-15-10-5 \quad 0 \quad 5 \quad 101520253035404550$

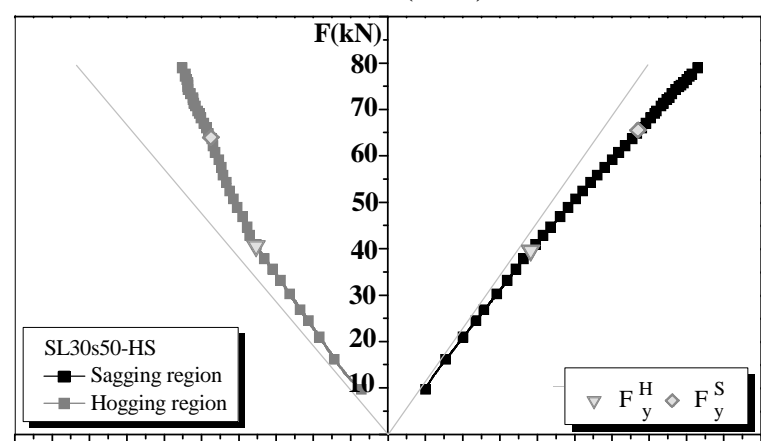
$-50-45-40-35-30-25-20-15-10$
Moment -5 (kN.m)

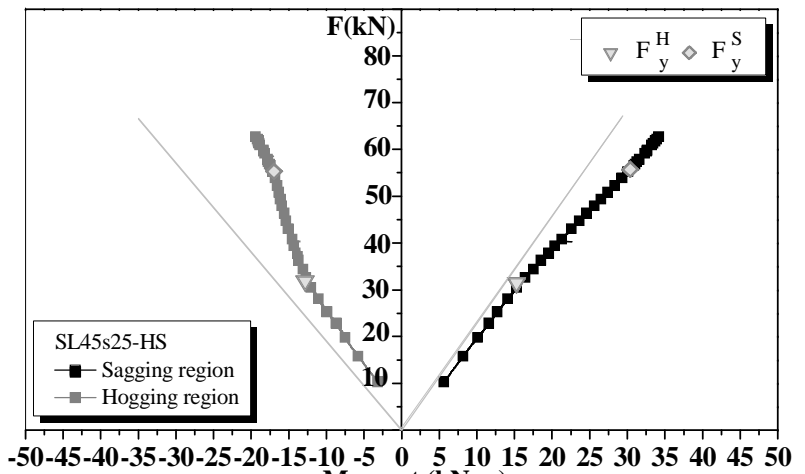

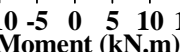

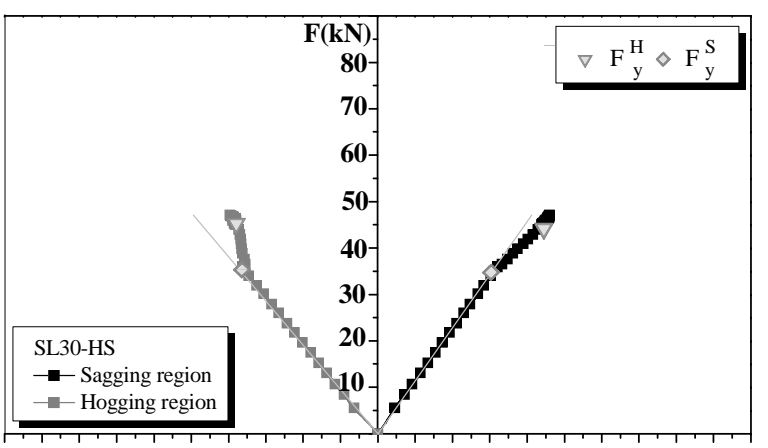

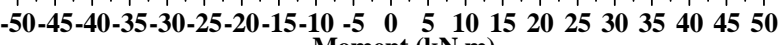

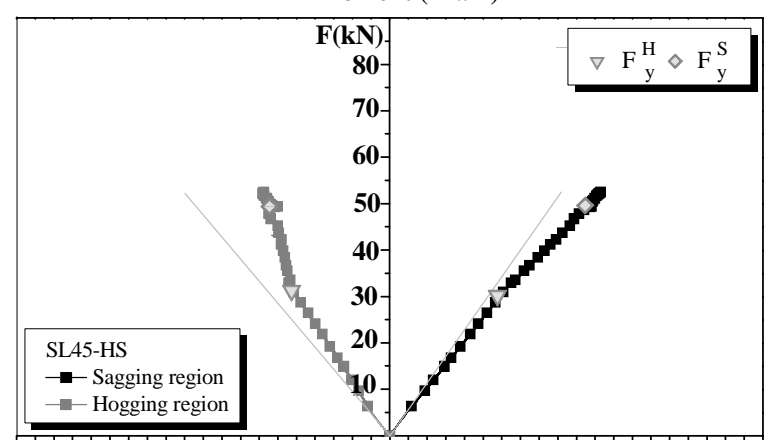

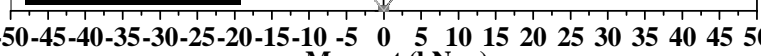
Moment (kN.m)

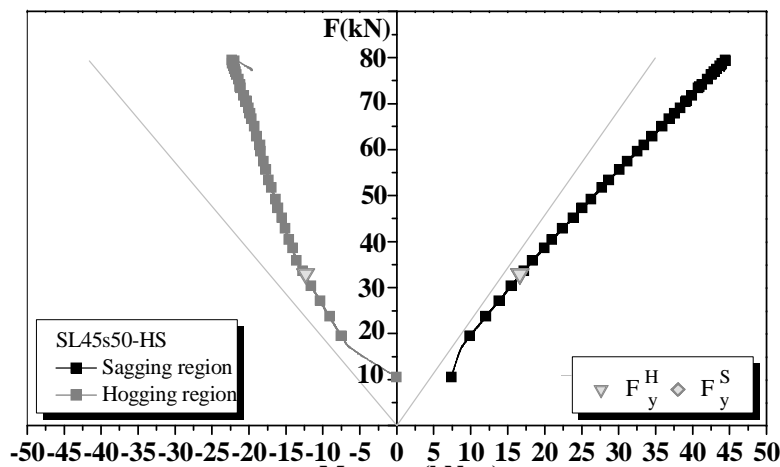

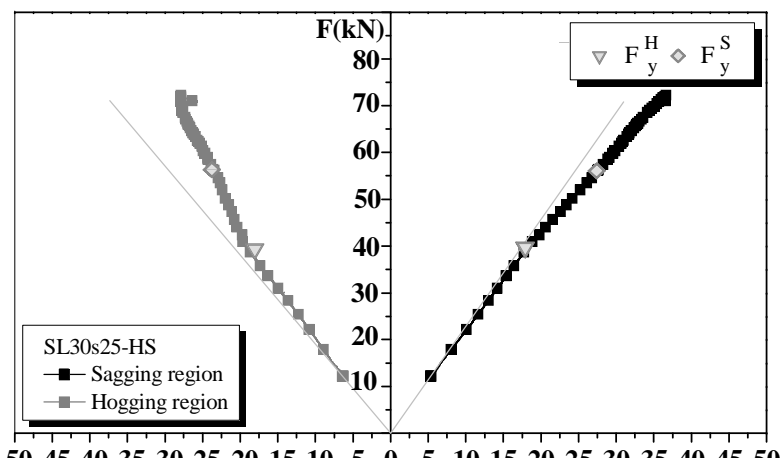

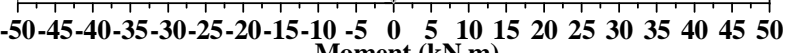

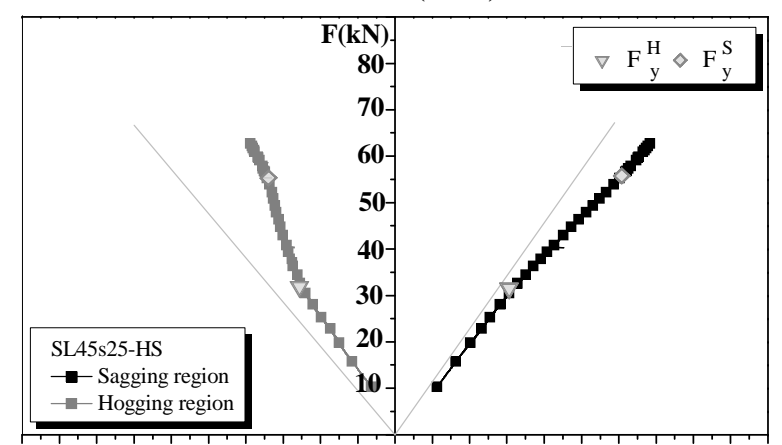

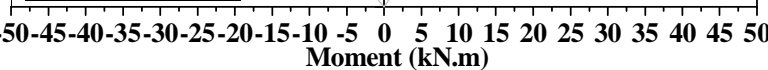

Fig. 14. Relationship between applied load and moment in the sagging and hogging regions for the series of slabs of the HS group: (a) SL15, (b) SL30, (c) SL45. 


\section{NOTATION}

The following symbols are used in this paper:

L Span length of the slab

$\delta \quad$ Coefficient of moment redistribution

$M_{\text {red }} \quad$ Moment in the critical section after redistribution

$M_{\text {elas }} \quad$ Elastic moment of a section calculated according to the theory of elasticity

$\eta \quad$ Moment redistribution percentage

$\mathrm{H} \quad$ Hogging Region

S Sagging Region

$\bar{F} \quad$ Average load

$\rho_{s} \quad$ Steel reinforcement ratio

$A_{s} \quad$ Cross sectional area of the steel bars in tension

$b \quad$ Width of the cross section

$d_{s} \quad$ Internal arm of the steel bars in tension

$F_{y}^{H} \quad$ Average loads at the formation of the plastic hinge at hogging region

$F_{y}^{S} \quad$ Average loads at the formation of the plastic hinge at sagging region

$u_{y}^{H} \quad$ Average deflection for $F_{y}^{H}$

$u_{y}^{S} \quad$ Average deflection for $F_{y}^{S}$

$\varepsilon_{c}^{H} \quad$ Maximum concrete strains registered at $\mathrm{H}$ region

$\varepsilon_{c}^{S} \quad$ Maximum concrete strains registered at $\mathrm{S}$ region

$\varepsilon_{s}^{H} \quad$ Maximum strains in steel bars at $\mathrm{H}$ region

$\varepsilon_{s}^{S} \quad$ Maximum strains in steel bars at $\mathrm{S}$ region

$\mathcal{E}_{f}^{H} \quad$ Maximum strains in the CFRP laminates at $\mathrm{H}$ region

$\varepsilon_{f}^{S} \quad$ Maximum strains in the CFRP laminates at $\mathrm{S}$ regions

$\Delta F_{y}^{H} \quad$ Increase of the loading carrying capacity when a plastic hinge was formed at the $\mathrm{H}$ region

$\Delta F_{y}^{S} \quad$ Increase of the loading carrying capacity when a plastic hinge was formed at the $\mathrm{S}$ region

$\varepsilon_{c, \max } \quad$ Maximum concrete compressive strain

$\bar{F}_{c r} \quad$ Cracking load

$\bar{F}_{y}^{H} \quad$ Load registered at the formation of the plastic hinge in the hogging region

$\bar{F}_{y}^{S} \quad$ Load registered at the formation of the plastic hinge in the sagging region 
Increase in terms of load carrying capacity provided by the strengthening technique

$F_{\text {cu }}^{\text {CFRP }}$

$\bar{F}_{u}$ of the strengthened slab

$F_{c u}^{R E F}$

$\bar{F}_{u}$ of the reference slabs

$\rho_{l, e q}$

Equivalent steel reinforcement ratio

$\rho_{l, e q}^{H}$

Equivalent steel reinforcement ratio of the hogging region

$\rho_{l, e q}^{S}$

Equivalent steel reinforcement ratio of the sagging region

$d_{f}$

Effective depth of the CFRP laminates

$E_{s} \quad$ Young's Modulus of the longitudinal tensile steel bars

$E_{f} \quad$ Young's Modulus of the CFRP laminates 